\title{
Neurotrophins: key regulators of cell fate and cell shape in the vertebrate nervous system
}

\author{
Miriam Bibel and Yves-Alain Barde ${ }^{1}$ \\ Department of Neurobiochemistry, Max-Planck Institute of Neurobiology, 82152 Planegg-Martinsried, Germany
}

Neurons are specialized cells with a complex morphology that represent the functional unit of the nervous system. They are generated in remarkable numbers, particularly in higher vertebrates. In the human brain, for example, there may be $\sim 85$ billion neurons (Williams and Herrup 1988). There is little cell division in the adult nervous system of vertebrates, and in most areas, the final number of neurons is determined early in development, at about the time when neurons extend axons (Oppenheim 1991). Neuronal numbers are controlled both by cell-intrinsic and cell-extrinsic programs. Cell-intrinsic programs govern basic aspects of neuronal differentiation in vertebrates, and a number of transcription factors have been shown to be expressed in well-defined areas of the nervous system (for review, see Rubenstein et al. 1998). Cell-extrinsic mechanisms play a prominent role in vertebrates. They involve the secretion of diffusible molecules controlling the survival of neurons produced in excess early in development, a process thought to help match the size of neuronal populations with the territory they innervate (Purves 1988; Oppenheim 1991). However, much of the developmental growth of the animal must still take place by the time these numerical adjustments are completed (Purves 1988). The neurons that have escaped elimination grow proportionally with the organism, enlarging their size by adding dendrites that grow out from the cell bodies.

Secreted proteins play a crucial role in the control of neuronal numbers and of dendritic growth. The best studied group is a family of structurally related molecules termed neurotrophins (Barde 1990). The first neurotrophin identified was originally designated "the" nerve growth factor (NGF; Levi-Montalcini 1966). However, only very few neurons were found to be NGF responsive in the central nervous system (CNS), and the isolation of brain-derived neurotrophic factor (BDNF) from the brain helped establish the concept that the fate and the shape of most vertebrate neurons can be regu-

${ }^{1}$ Corresponding author.

E-MAIL yves.barde@neuro.mpg.de; FAX 49-89-8578-3749.

Article and publication are at www.genesdev.org/cgi/doi/10.1101/ $\operatorname{gad} .841400$. lated by diffusible growth factors (Hofer and Barde 1988). In the context of the regulation of neuronal shape, a particularly attractive and important feature of the neurotrophins is that they are synthesized and released by neurons and that both their biosynthesis and secretion depend on neuronal activity (Thoenen 1995).

In addition to ngf and bdnf, two other neurotrophin genes have been identified in mammals, neurotrophin-3 (nt3) and neurotrophin-4/5 (nt4/5). These four genes encode pre-pro-neurotrophins. The processed proteins have a size of $\sim 13,000 \mathrm{D}$, and they exist in solution as noncovalently linked homodimers (for review, see Barde 1990; Ibáñez 1998). They all have very basic isoelectric points, a somewhat unusual property for secreted proteins, which may serve the purpose of limiting their range of action. The structural hallmark of the protomer is a characteristic arrangement of the disulfide bridges known as the cystine knot (McDonald et al. 1991), later identified in other secreted proteins such as the plateletderived growth factors and the transforming growth factor- $\beta$ s (TGF- $\beta$ s; McDonald and Hendrickson 1993). With the exception of NT4/5, neurotrophin sequences are highly conserved in mammals. In bony fishes, more neurotrophin and receptor genes have been isolated than in mammals (for review, see Hallböök 1999). Based on sequence comparisons and on the isolation of neurotrophin genes in various vertebrates, it is thought that $n g f / n t 3$ and $b d n f / n t 4 / 5$ evolved from separate duplication events (Hallböök 1999). The most primitive neurotrophin genes have been isolated from jawless fishes, a river lamprey and the Atlantic hagfish. The jawless fish lineage diverged about 460 million years ago in vertebrate history, and the neurotrophin receptors of the trk family (see below) seem to have coevolved with the neurotrophin genes (Hallböök, 1999). So far, no neurotrophin-like sequences have been detected in invertebrates typically used by geneticists, and unlike other growth factors such as members of the Wnt, fibroblast growth factor or TGF- $\beta$ families, genes coding for neurotrophins and their receptors have not been identified in the genome of the nematode Caenorhabditis elegans (Bargmann 1998). Clearly then, a nervous system can be put together in the absence of neurotrophins, including precise wiring, chemical neurotransmission, and the 
elimination of neurons during development. This raises questions about the benefit of the neurotrophin signaling system. One speculation relates to the ability of the neurotrophins to control the survival and growth of neurons and of their branches. Given the very large numbers of neurons that characterize the nervous system of higher vertebrates, it may have proved useful to generate an intercellular signaling system to modulate intrinsic programs of differentiation. Also, there is increasing evidence for an involvement of neurotrophins in activitydependent structural plasticity as part of a long-lasting response to environmental stimuli, a process likely to be of special significance in long-lived organisms.

This review deals first with a peculiarity of the neurotrophin signaling system, which is the use of two different types of cell surface receptors. It then describes examples of the biological activities of the neurotrophins on neurons, with an emphasis on in vivo work.

\section{Neurotrophin signaling}

\section{Neurotrophin signaling uses a two-receptor system}

Neurotrophins bind to two different classes of transmembrane receptor proteins, the Trks and the neurotrophin receptor p 75 (Fig. 1). This dual system allows the transduction of very different signals following ligand binding, which can be as contrasted as signaling cell death through p75 or cell survival through the Trk receptors. These two classes of receptors also directly interact, allowing fine tuning and cross talk.

The Trk (tropomyosin receptor kinase) receptors belong to the family of receptor tyrosine kinases, and three trk genes have been identified in mammals. The TrkA protooncogene was first identified as an NGF receptor (Kaplan et al. 1991; Klein et al. 1991), followed by TrkB and TrkC (for review, see Barbacid 1994). NGF is the preferred ligand for TrkA, BDNF and NT4/5 are preferred for TrkB, and NT3 for TrkC (Barbacid 1994). These specificities are not absolute, and NT3 is also a ligand for TrkA and TrkB. Whereas the tyrosine kinase domains are highly related $(\sim 80 \%$ amino acid identity), the extracellular domains are more divergent $(\sim 30 \%)$. Unlike with the neurotrophins, a Trk receptor ortholog could be identified in an invertebrate, the snail Lymnaea stagnalis (van Kesteren et al. 1998).

P75 was the first member to be molecularly cloned (Johnson et al. 1986; Radeke et al. 1987) of a large family of receptors, which includes both TNF receptors, Fas (Apo-1/CD95), CD40, and 15 other members (Smith et al. 1994; Grell and Clauss 2000). The defining motifs of this receptor family are cysteine repeats in the extracellular domain, which form the ligand-binding domain. With the exception of the neurotrophins, all other known ligands of this receptor family are trimeric proteins that lead to the trimerization of the receptor following ligand binding. None of these receptors exhibits any intrinsic catalytic activity, and they signal by associating with, or dissociating from, cytoplasmic interactors. Indeed, there are several protein association motifs p75 TrkA,B,C

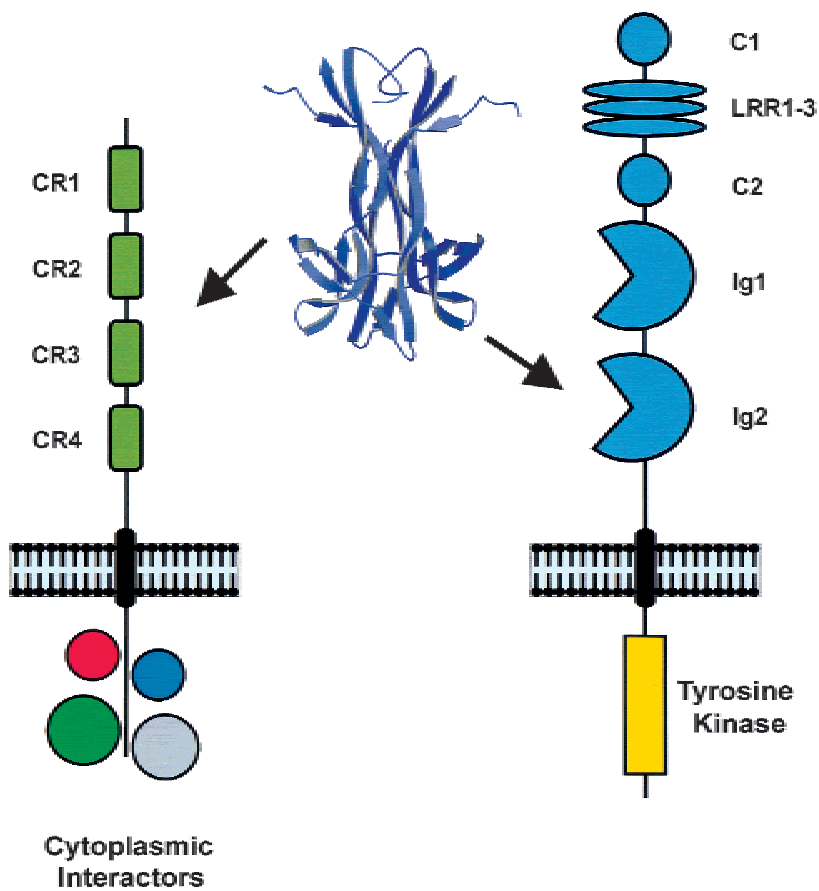

Figure 1. The two receptor classes of the neurotrophins. P75 is a transmembrane glycoprotein receptor of $\sim 75 \mathrm{kD}$. There are four cysteine repeats (CR1-CR4) in the extracellular domain. P75 is palmitoylated at a conserved cysteine residue in the intracellular juxtamembrane region (Barker et al. 1994). Signaling of p75 occurs through cytoplasmic interactors. The Trk receptors are transmembrane glycoproteins of $\sim 140 \mathrm{kD}$. They are tyrosine kinases with an extracellular ligand-binding domain containing multiple repeats of leucine-rich motifs (LRR1-3), two cysteine clusters (C1, C2), two immunoglobulin-like domains (Ig1, Ig2), and a single transmembrane domain (Schneider and Schweiger 1991). Binding specificity of the Trk receptors is mostly determined by the second Ig-like domain, whereby each Trk receptor binds the corresponding ligand through a distinct specific sequence (Urfer et al. 1995, 1998). NGF has been crystallized in complex with the Ig2 domain of the TrkA receptor, revealing a ligand-receptor interface of two patches, where one seems to be a conserved binding motif for all family members, the other specific for the interaction between NGF and TrkA (Wiesmann et al. 1999). Two different binding epitopes for p75 have been identified on the surface of NGF indicating that the neurotrophins could bind to p75 and Trk simultaneously. P75 associates and can be coprecipitated with all three Trk receptors.

in the cytoplasmic domain of p75. It is distantly related to the so-called death domain of other members of the family (Chapman 1995; Feinstein et al. 1995). In Fas and p75, this domain consists of a bundle of six short $\alpha$-helices spanning $~ 90$ amino acids that form a novel type of fold (Liepinsh et al. 1997). Recently, a novel TNF receptor-related receptor has been identified and designated the ectodysplasin receptor (EdaR; Barsh 1999; Headon and Overbeek 1999). It is involved in hair follicle induc- 
tion and is the first member of the family to be clearly related to p75 at the level of the primary structure, both in the first cysteine-repeat and in the cytoplasmic domain. Also of note (see below) is a short sequence of the intracellular domain of p75 that is clearly related to that of mastoparan, a 14mer peptide derived from wasp venom that is capable of directly activating $G$ proteins (Feinstein and Larhammar 1990). The C terminus forms a consensus sequence found in several other proteins associating with postsynaptic densities, such as PSD-95 (Kornau et al. 1995).

All neurotrophins bind to p75 with an affinity of $\sim 10^{-9} \mathrm{M}$ (Rodriguez-Tébar et al. 1990). This is a lower affinity than that determined for neurotrophin binding on neurons (typically $10^{-11} \mathrm{M}$ ). However, high-affinity binding of neurotrophins to neurons cannot be simply explained by the presence of Trk receptors, as the majority of the neurotrophin-binding sites formed by Trk receptors are of low affinity. In addition, p75 can also form high-affinity sites on neurons (Dechant et al. 1997). It is thus misleading to refer to Trk or p75 as being high- or low-affinity receptors, and it appears that the formation of highaffinity binding and specific binding sites for neurotrophins on neurons is most likely a result of the association of p75 with Trk receptors (Mahadeo et al. 1994).

P75 binds more than just neurotrophins. Indeed, a protein isolated from the snail Lymnaea stagnalis, designated CRNF (for cysteine-rich neurotrophic factor), with no sequence similarities with the neurotrophins, binds with similar affinity to p75 (Fainzilber et al. 1996). Also, a rabies virus glycoprotein has been recently reported to bind to p75 (Tuffereau et al. 1998).

\section{Signal transduction through the Trk receptors}

Binding of the neurotrophins to the Trk receptors leads to receptor tyrosine phosphorylation (for review, see Friedman and Greene 1999). This triggers the activation of pathways leading to the prevention of programmed cell death and neuronal differentiation. Ligand-induced dimerization (Jing et al. 1992) results in the phosphorylation of specific tyrosine residues, located in the socalled activation loop of the tyrosine kinase domain (Cunningham and Greene 1998). Phosphorylation of these residues leads to an open conformation of the receptor resulting in trans-phosphorylation and allowing the access of substrates to the kinase. Phosphotyrosine residues on Trk receptors then act as docking sites for adapter molecules (Fig. 2). Two specific phosphorylated tyrosine residues, located in the juxtamembrane domain and in the $\mathrm{C}$ terminus (Y490 and Y785 in TrkA), serve as docking sites for adapter molecules (Obermeier et al. 1994; Stephens et al. 1994; for review, see Friedman and Greene 1999).

First, phosphorylated Y490 binds Shc via a PTB (phosphotyrosine binding) domain (Dikic et al. 1995) and phosphorylates it. The recent finding of Shc analogs (NShc, Sck; Nakamura et al. 1998) raises the question of recruitment of different Shcs that may be specific for
TrkA, TrkB, or TrkC. This could form a basis for Trkspecific responses (see below). Interestingly, elimination of the Shc binding site in the $\operatorname{trk} B$ gene revealed distinct responses to BDNF and NT4/5 (Minichiello et al. 1998). NT4/5-dependent sensory neurons were mostly lost in trk $B^{\text {Shc/Shc }}$ mutant mice, whereas BDNF-dependent neurons were only modestly affected. This tyrosine seems also to be the docking site for another membraneanchored adaptor protein, FRS2 (Kouhara et al. 1997; Meakin et al. 1999), which is tyrosine phosphorylated in response to NGF and BDNF (Easton et al. 1999). FRS2 was originally described as identical to SNT (Kouhara et al. 1997), but they seem to have different properties, as SNT is predominantly a nuclear protein, whereas FRS2 is membrane anchored (Rabin et al. 1993). Also, SNT seems to bind to a conserved sequence motif, KFG, in the juxtamembrane domain of the Trk receptors (Peng et al. 1995). However, the sequence of SNT has not been reported yet.

Second, phosphorylation of Y785 induces binding via SH2 domain and phosphorylation of phospholipase C- $\gamma$ (PLC- $\gamma$ ). Furthermore, phosphorylated Y785 also leads to association of TrkA with CHK (Csk homologous kinase), which seems to be involved in NGF-promoted neurite outgrowth via MAPK, as suggested by the effect of antibodies to CHK (Yamashita et al. 1999a). Additional adapter proteins seem to play a role in Trk signaling; for example, Crk, the small G protein Rap1, or C3G (Matsuda et al. 1994; Torres and Bogenmann 1996; York et al. 1998).

Three main signaling cascades are activated by the Trk receptors and their substrates. First, the activation of the Ras/Raf/MEK/MAPK pathway results from the formation of a variety of complexes of adapter molecules. Phosphorylated Shc leads to the activation of the Ras/ Raf/MEK/MAPK pathway (for review, see Kaplan and Miller 2000). Phospho-Shc binds to the Grb2-SOS complex, which activates Ras, and MAP kinase is activated through Raf- and MEK. Similarly, phosphorylated FRS2 recruits a complex of the tyrosine phosphatase SHP-2/ Grb2/SOS and activates Ras/Raf/MEK/MAPK (Kouhara et al. 1997; Wright et al. 1997; Hadari et al. 1998). Also, SNT seems to activate this pathway, which mediates neuritogenesis (Stephens et al. 1994). Other docking molecules seem to form complexes with Grb2/SOS, such as rAPS and SH2-B (Qian et al. 1998). They were identified in developing neurons and may be involved in neuronal differentiation. This complexity of activation allows a sustained activation of the MAPK pathway in response to neurotrophins, as well as a fine-tuning of the responses.

Second, IRS (insulin receptor substrates IRS-1 and IRS2) and Gab-1 (Grrb-associated binder-1) are adapter proteins that mediate the association and activation of PI3K (Holgado-Madruga et al. 1997; Yamada et al. 1997), as PI3K does not directly interact with the Trk receptors. PI3K is especially implicated in neuronal survival via the activation of PKB/AKT kinase (Franke et al. 1997; Crowder and Freeman 1998), resulting in phosphorylation and inactivation of the proapoptotic protein $\mathrm{BAD}$ of the Bcl-2 


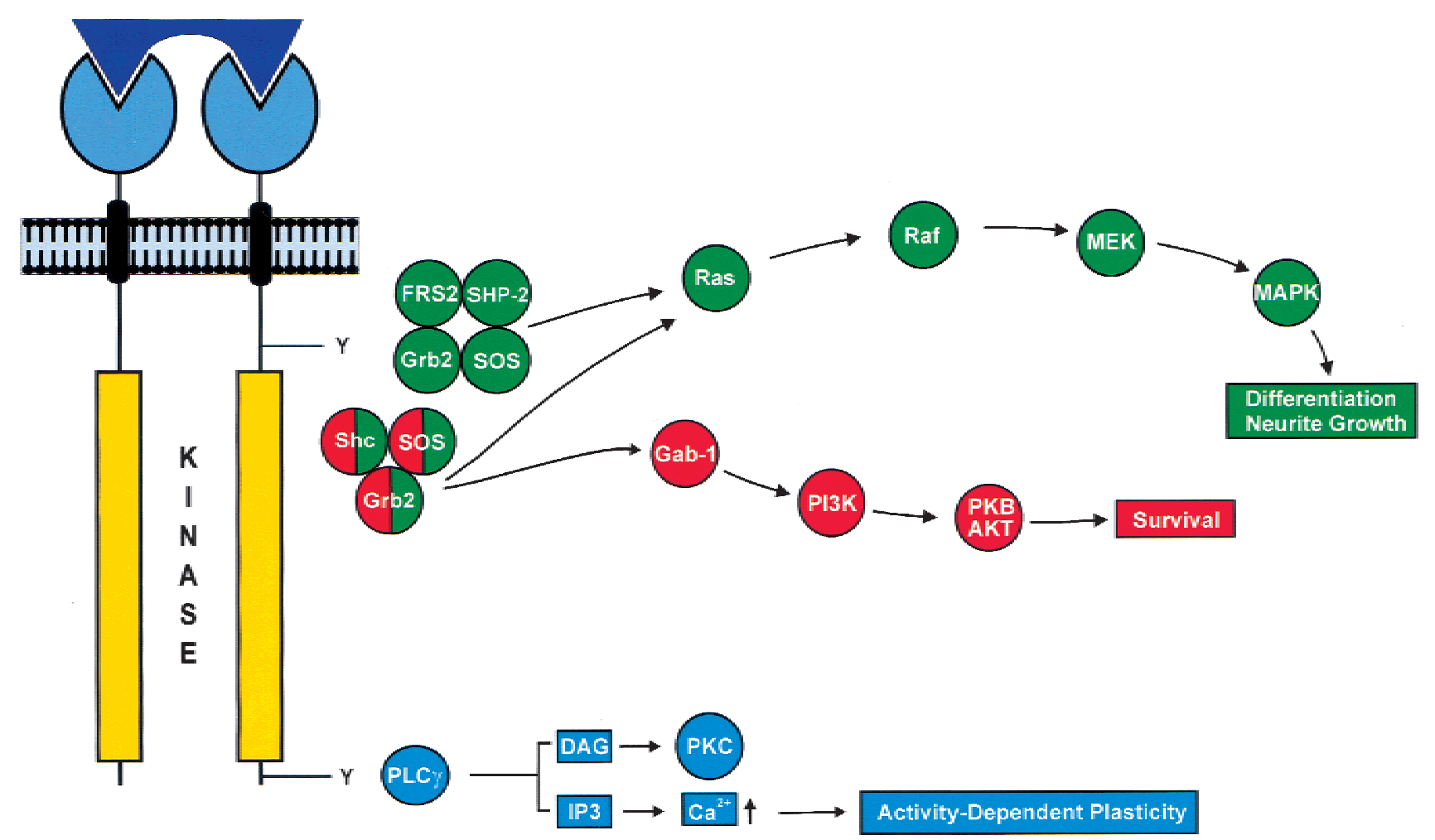

Figure 2. Signaling through the Trk receptors-the main pathways. Neurotrophin binding to Trk receptors triggers dimerization leading to the activation of different signaling pathways through recruitment of various adapter molecules. The main binding sites for Trk substrates are two tyrosine residues that, on activation of the Trk receptors, become phosphorylated. Two complexes of adapter molecules bind to the tyrosine residue located in the juxtamembrane region of the Trk receptor, the Shc/Grb2/SOS and the FRS2/ SHP-2/Grb2/SOS complex. Ras/Raf/MEK/MAPK induces the differentiation of neurons and neurite growth. The PKB/AKT pathway mediates the survival functions of the neurotrophins. The phosphorylated tyrosine in the $C$ terminus recruits PLC $\gamma$, which catalyses the cleavage of the substrate PIP2 to DAG and IP3, with DAG inducing activation of PKC and IP3 leading to release of calcium from internal stores.

family (Datta et al. 1997). PKB/AKT also leads to the phosphorylation of the Forkhead transcription factor, which controls the expression of genes involved in cell death, such as Fas ligand (Brunet et al. 1999).

Third, the association of PLC- $\gamma$ with Trk regulates intracellular $\mathrm{Ca}^{2+}$ levels and protein kinase $\mathrm{C}$ activity via cleavage of the substrate PIP2 to DAG and IP3. This pathway seems to play an important role in neurotrophin-mediated neurotrophin release (Canossa et al. 1997) and in synaptic plasticity (M. Korte, pers. comm.). It has also been reported that the PLC- $\gamma$ pathway regulates the neuron-specific intermediate filament protein peripherin (Loeb et al. 1994).

Most studies on Trk signaling were performed with TrkA and NGF, not least because of the availability of PC12 cells, which express both TrkA and p75. However, it appears unlikely that all three Trk receptors trigger identical signaling pathways. For example, it has been noted with sympathetic neurons that the activation of TrkA by NGF and that of TrkC by NT3 lead to very different biological outcomes (see below). Moreover, even the activation of the same Trk receptor by different ligands seems to trigger different signaling events. For example, activation of TrkB by BDNF or NT4/5 does not always lead to identical biological effects. Using a knock-in approach, Fan et al. substituted the bdnf with the $n t 4 / 5$ gene (Fan et al. 2000). Whereas the levels of NT4/5 are comparable to those of BDNF, the mutant mice have more sensory neurons, show reduced body weight, and are infertile. Also, the activation of TrkA on sympathetic neurons by NGF or NT3 differentially regulates survival and neuritogenesis (Belliveau et al. 1997). It is possible that different time courses of activation triggered by NGF and NT3 may play a role.

An interesting and neuron-specific aspect of neurotrophin signaling is the retrograde transport of signals from axon terminals back to the cell body of neurons. This process seems to involve the internalization of the neurotrophin and the retrograde transport of a ligandreceptor complex, including Trk receptors (Bhattacharyya et al. 1997; Riccio et al. 1997). The mechanisms involved in the retrograde transport of such complexes have not been fully clarified yet, though there is evidence for signaling endosomes (Grimes et al. 1996). Also, there is an intriguing report indicating that retrograde signaling may occur much faster than neurotrophin transport (Senger and Campenot 1997) by mechanisms that remain unclear. 
In summary, neurotrophin signaling through Trk receptors shows a remarkable redundancy allowing the regulation of multiple responses to neurotrophin stimulation depending on the cellular context. Also, the binding of several adapter proteins makes it possible to amplify and diversify receptor-mediated signals. How these different signaling pathways are integrated remains an important open question at this point.

\section{Splice variants of the Trk receptors}

Splice variants have been described for all three Trk receptors. These receptor molecules have either deletions in the extracellular domain or intracellular truncations including the tyrosine kinase domain (for human Trks, see Shelton et al. 1995). Insert variants of the extracellular domain of TrkA and TrkB were found to influence ligand specificity. In particular, a TrkB splice variant lacking exon9 in the extracellular domain shows decreased interaction with NT4/5 and NT3 (Strohmaier et al. 1996). Similarly, a TrkA variant has been described with an increased specificity for NGF and a decreased specificity for NT3 (Clary and Reichardt 1994). Splice variants of TrkC, and especially of TrkB, lacking the tyrosine kinase domain are expressed at high levels in the mature brain (Klein et al. 1990). However, their biological roles remain unclear. The truncated TrkB receptor isoforms, designated as $\mathrm{T} 1$ and $\mathrm{T} 2$, contain short intracellular domains (23 and 21 amino acids; Klein et al. 1990; Middlemas et al. 1991). They are up-regulated during early postnatal development and predominate over full-length TrkB in the adult brain (Fryer et al. 1996). These truncated receptors are often expressed in nonneuronal cells that do not express full-length TrkB (Klein et al. 1990). They internalize BDNF and may restrict its availability (Biffo et al. 1995). The truncated Trk splice variants are often discussed as dominant negative modulators of Trk signaling, and there is convincing evidence in reconstituted systems that negative modulation may occur (Eide et al. 1996; Ninkina et al. 1996). However, too little is known about the cellular and subcellular localization of these receptors on neuronal cell bodies, axons, and dendrites to appreciate the physiological implications of these findings.

\section{Signal transduction through the neurotrophin receptor $\mathrm{p} 75$}

Whereas it is now clear that p75 transduces signals following neurotrophin binding, the function of this receptor varies considerably depending on the cellular context in which it is expressed (for review, see Barker 1998). This may be one of the consequences of the use of cytoplasmic interactors for signal transduction. Furthermore, many cells coexpress Trk and p75 receptors, and receptor interaction modulates the outcome of neurotrophin binding (Bibel et al. 1999).

The first indication for the signaling function of $\mathrm{p} 75$ was the finding that p75 mediates sphingomyelin hydro- lysis and production of ceramide following neurotrophin binding (Dobrowsky et al. 1994, 1995). In cultured mesencephalic neurons, ceramide production was linked with the release of dopamine (Blöchl and Sirrenberg 1996). p75 seems to interact with caveolin. Caveolae are presumably the site of neurotrophin-induced sphingomyelin hydrolysis (Bilderback et al. 1997, 1999). Ceramide production is known to follow TNF binding to its receptor and to lead to NF- $\mathrm{B}$ activation (Wiegmann et al. 1994). Likewise, in Schwann cells expressing p75, but no catalytic Trk receptors, NF- $\mathrm{kB}$ activation was observed following the addition of NGF (Carter et al. 1996). Surprisingly, neither BDNF nor NT3 led to a detectable activation of NF-кB. As is the case with TNF receptor 1 signaling, it appears that activation of NF- $\kappa \mathrm{B}$ prevents cell death (Liu et al. 1996; Hamanoue et al. 1999). Evidence that preventing the activation of NF- $\mathrm{KB}$ causes cell death has been provided both with neuronal cultures and with a Schwann cell line (Maggirwar et al. 1998).

Beyond the activation of NF- $\mathrm{kB}$ that seems to mediate cell survival, there are also clear indications that p75 activation by neurotrophins causes programmed cell death. Cell death signaling involves caspase activation, as well as Bax/Bad, Bcl-2, and Bcl-xL (Coulson et al. 1999; Soilu-Hänninen et al. 1999|, but the details of the pathway linking p75 with cell death execution are far from clear. Inhibition of Jun kinase (JNK) activity blocks apoptosis through p75, suggesting that JNK plays a significant role in p75-mediated apoptosis (Yoon et al. 1998). However, JNK activation cannot always be detected in p75mediated apoptosis, and there is evidence that p53 and the p53-related protein p73 play a role; however, the link between these molecules and p75 is unclear (Pozniak et al. 2000).

Whereas overexpression of p75 causes cell death in a ligand-independent fashion, it is unclear if the levels of p75 expression in the nervous system suffice to cause cell death in the absence of ligand (see Rabizadeh et al. 1993; Barrett and Bartlett 1994; Majdan et al. 1997). In vivo, there is evidence for NGF-mediated cell death through p75, especially in structures where TrkA is expressed later in development than p75 (see below). In general, it seems that neurotrophins can only induce cell death through p75 in cells not expressing their specific Trk receptors (Bamji et al. 1998; Yoon et al. 1998). By contrast, coactivation of the appropriate Trk receptors inhibits neurotrophin-induced p75-mediated apoptosis, as demonstrated with cultured oligodendrocytes and neurons (Davey and Davies 1998). Trk activation can block p75-mediated cell death by several mechanisms. For example, the interaction of both receptors may disrupt the interaction of $\mathrm{p} 75$ with a death-transducing protein by analogy with the interaction of the TNF receptor with the suppressor of death domain (SODD) protein (Jiang et al. 1999).

A number of interactors and their possible functions have been described for p75 (Fig. 3), many of them as a result of yeast two-hybrid screens. P75 interactors involved in transducing cell death include a ubiquitously expressed zinc finger protein designated NRIF (neuro- 
Figure 3. P75 recruits cytoplasmic interactors to signal. Several cytoplasmic interactors of $\mathrm{p} 75$ have been identified that mediate different biological functions. NADE (p75NTR-associated cell death executor), NRIF (neurotrophin receptor-interacting factor) and NRAGE (neurotrophin receptor-interacting MAGE homolog) are involved in the induction of cell death through p75. NRIF and NRAGE also lead to cell cycle arrest as well as SC-1 (Schwann cell factor-1). The GTPase RhoA modulates neurite growth. The TRAFs and FAP-1 associate with p75, leading to the activation of NF-кB. Kinases such as ERK1, ERK2, and a p75-associated kinase also interact with $\mathrm{p} 75$, but their physiological relevance is not clear.

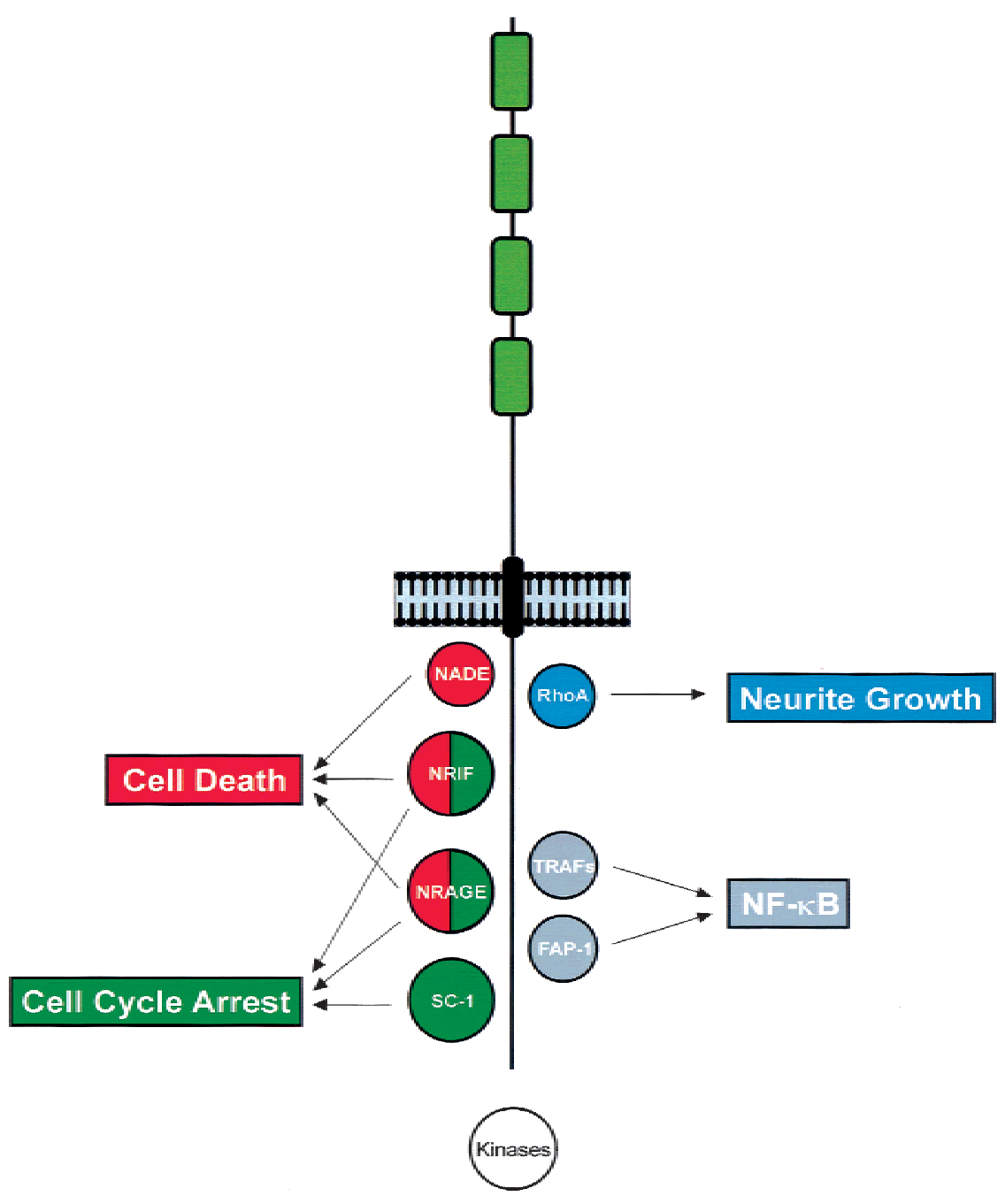

cer tissues), mediates NGF-dependent apoptosis in sympathetic neuron precursor cells (Salehi et al. 2000). NRAGE is widely expressed, mostly in developing tissues. It also causes cell cycle arrest when overexpressed in transfected cells, suggesting that p 75 might play a role in growth control through the interaction with NRAGE. Interestingly, NRAGE disrupts the interaction between p75 and TrkA.

A protein designated NADE (p75 NTR-associated cell death executor) associates with p75 after NGF binding but not after binding of BDNF, NT3 or NT4/5 (Mukai et al. 2000). It too seems to be involved in p75-mediated apoptosis.

As noted, the intracellular domain of p75 contains a sequence related to mastoparan. In view of this, it is intriguing to note that the GTPase RhoA has been isolated as a p75 interactor in a yeast two-hybrid screen (Yamashita et al. 1999b). Indeed, mastoparan had been shown previously to activate Rho proteins (Koch et al. 1991), and p75 turns out to constitutively activate RhoA, whereas neurotrophin binding to $\mathrm{p} 75$ blocks this activation. The link between p75 and Rho seems to be functionally relevant, as the modulation of neurite out- 
growth in p75-expressing neurons by neurotrophins mimics the results obtained following Rho inactivation.

Using coimmunoprecipitation and phosphorylation assays, a p75-associated kinase (Canossa et al. 1996), as well as ERK1 and ERK2 (Volonté et al. 1993), were shown to interact with $\mathrm{p} 75$. The functional significance of these associations is not clear, though p75 is serine phosphorylated in the intracellular domain. Association of TRAF6 with p75 after ligand binding leads to the activation of NF- $\mathrm{B}$ (Khursigara et al. 1999). A recent report suggests that all members of the TRAF family interact with p75 (Ye et al. 1999).

Curiously, despite structural and functional similarities between p75 and members of the TNF receptor/Fas/ CD40 family, it is unclear if in nontransformed cells p75 uses interactors similar to those used by TNFR and CD95. As noted, p75 may be unique in having dimeric ligands. Exceptions may be TRAFs and FAP-1 (Irie et al. 1999), though the relevance of these interactions with p75 is less clear than in the case of the TNFRs and CD95.

Among the most obviously relevant proteins interacting with p75 are the three Trk receptors. Both receptor types are often expressed by the same cells, and they form a complex that can be immunoprecipitated after solubilization (Bibel et al. 1999). Both the intra- and the extracellular domains participate in this interaction, which is also dependent on the state of phosphorylation of the Trk receptors (Bibel et al. 1999). This interaction is functionally relevant in several important ways. First, receptor association leads to high-affinity neurotrophin binding, which is crucial in view of the limiting amounts of neurotrophins in vivo (Hempstead et al. 1991; Benedetti et al. 1993; Davies et al. 1993; Barker and Shooter 1994; Lee et al. 1994; Mahadeo et al. 1994; Horton et al. 1997). Second, receptor association increases ligand discrimination by the Trk receptors, which is especially important in the case of TrkA and TrkB, that bind more than one neurotrophin (Benedetti et al. 1993; Bibel et al. 1999). Third, the proximity of p75 and Trk receptors in the membrane allows the signaling pathways triggered by both receptors to interact.

\section{Variants of the p 75 receptor}

Like several other members of its family, p75 is processed by proteolysis, and relatively high levels of a soluble form of $\mathrm{p} 75$ have been measured in various body fluids (Zupan et al. 1989). In addition to the major transcript encoding the full-length receptor, a minor transcript exists encoding a protein truncated in the extracellular domain that has lost its ability to bind neurotrophins (Dechant and Barde 1997). The first targeted mutation of the p75 gene was introduced in the exon left out in this minor p75 transcript and as a result, the truncated protein can still be detected in the mutant. Its transmembrane and cytoplasmic domain is identical to the full-length protein, and as several intracellular proteins bind to the cytoplasmic domain of p75, the possibility exists that the presence of even small amounts of this truncated protein may be functionally relevant. Indeed, a new targeted disruption of the $\mathrm{p} 75$ gene leading to the absence of detectable protein results in a phenotype that is more severe than the previous mutation (Lee et al. 1992). About $40 \%$ of the mutant animals die during embryogenesis, apparently from defects in the formation of blood vessels (G. Dechant and E. Casademunt, pers. comm.).

\section{Neurotrophin receptor expression is highly regulated}

In contrast to other signaling systems, the neurotrophins are not ubiquitously expressed. The exquisite neuronal specificity of neurotrophins results from the selective expression pattern of the Trk receptors, for example, in subgroups of sensory neurons (Tessarollo et al. 1993). In addition, the neurotrophins are primarily localized in the target areas innervated by responsive PNS axons (Davies 1994). In the CNS, few neurons express TrkA (mostly the basal forebrain cholinergic neurons), whereas TrkB is widely expressed, explaining the multitude of actions of BDNF in the CNS. TrkC is typically expressed early in development (Tessarollo et al. 1993). P75 is coexpressed with the Trk receptors in many neuronal populations (Chao and Hempstead 1995). Its expression profile is highly developmentally regulated (Bothwell 1995). During postnatal development, p75 is down-regulated in most parts of the central nervous system but is rapidly induced after nerve lesion or seizure (Roux et al. 1999). This further links p75 with cell death in pathological situations. Finally, p75 is also expressed by many cells by the time they become postmitotic cells and/or migrate, such as neural crest cells (Fariñas et al. 1998). The strong expression of $\mathrm{p} 75$ by neurons at the time when they form axons suggests a link between this receptor and process outgrowth (Yamashita et al. 1999b).

\section{Nuclear targets of neurotrophin signaling}

How neurotrophin signaling converges to activate or repress gene transcription is far from clear. Both the cyclic AMP response element binding protein CREB and c-fos are clearly involved in some of the rapid responses following neurotrophin binding to the Trk receptors (Finkbeiner et al. 1997). CREB kinases activate CREB, which regulates bcl-2 transcription and thereby inhibits the cell death machinery, perhaps in concert with other CREB target genes that remain elusive (Finkbeiner 2000). Additional transcription-dependent survival pathways have been proposed, involving in particular the transcription factor Forkhead 1 (FKHRL1; Brunet et al. 1999). FKHRL1 induces apoptosis by increasing levels of Fas ligand (FasL). PKB/AKT directly phosphorylates and inhibits FKHRL1, thereby promoting cell survival (Brunet et al. 1999). Finally, CREB itself regulates the transcription of the BDNF gene (Tao et al. 1998). Interestingly, CREB is also implicated in mechanisms of long-lasting activitydependent synaptic plasticity (Silva et al. 1998). 


\section{Neurotrophins control the survival of neurons}

\section{Neurotrophins prevent programmed cell death}

Sensory ganglia One of the most extensively studied properties of the neurotrophins is their ability to keep alive subpopulations of sensory neurons. Indeed, BDNF was identified and purified on the basis of its ability to prevent the death of sensory neurons not responding to NGF (Barde et al. 1982). The dorsal root ganglias (DRGs) have been especially useful in establishing correlations between the properties of each neurotrophin and subpopulations of neurons identified on the basis of their physiological properties and connections (Fig. 4). Animals treated with NGF antibodies at appropriate time points or mice carrying a deletion in the ngf or the $\operatorname{trk} A$ gene lack all of the smallest, as well as some of the mid-sized, neurons (for review, see Snider 1994). This corresponds to a loss of all unmyelinated, and $\sim 50 \%$ of the (mostly thinly) myelinated, axons. In such animals, the detection of potentially painful stimuli is completely eliminated. Large losses of DRG neurons have also been reported in mice with a null mutation in the $n t 3$ gene, including the loss of afferents innervating spinal cord motoneurons (Snider 1994). Bdnf-/- animals lack slowly adapting mechanoreceptors, and nt4/5-/- mice lack down-hair receptors (Carroll et al. 1998). All four null mutations lead to very specific losses of peripheral sensory innervation, as extensively investigated in the mouse whisker pad (Rice et al. 1998).

The peripheral sensory system has also helped to examine the question of neurotrophin receptor specificity and usage in vivo. The most straightforward case is that of NGF and TrkA, as deletion of either gene leads to a very similar phenotype. This strongly suggests that TrkA is a necessary receptor for mediating the in vivo survival activity of NGF (Snider 1994). By and large, the deletion of TrkB corresponds to what may be expected from the loss of BDNF and NT4/5 function. However, the situation with TrkC turned out to be more complex, as the neuronal losses in the sensory system are significantly more severe in $n t 3-/-$ compared with trkC-/animals (Snider 1994). Subsequent studies involving the analysis of double mutants indicated that early in development, NT3 uses both TrkA and TrkB to mediate its

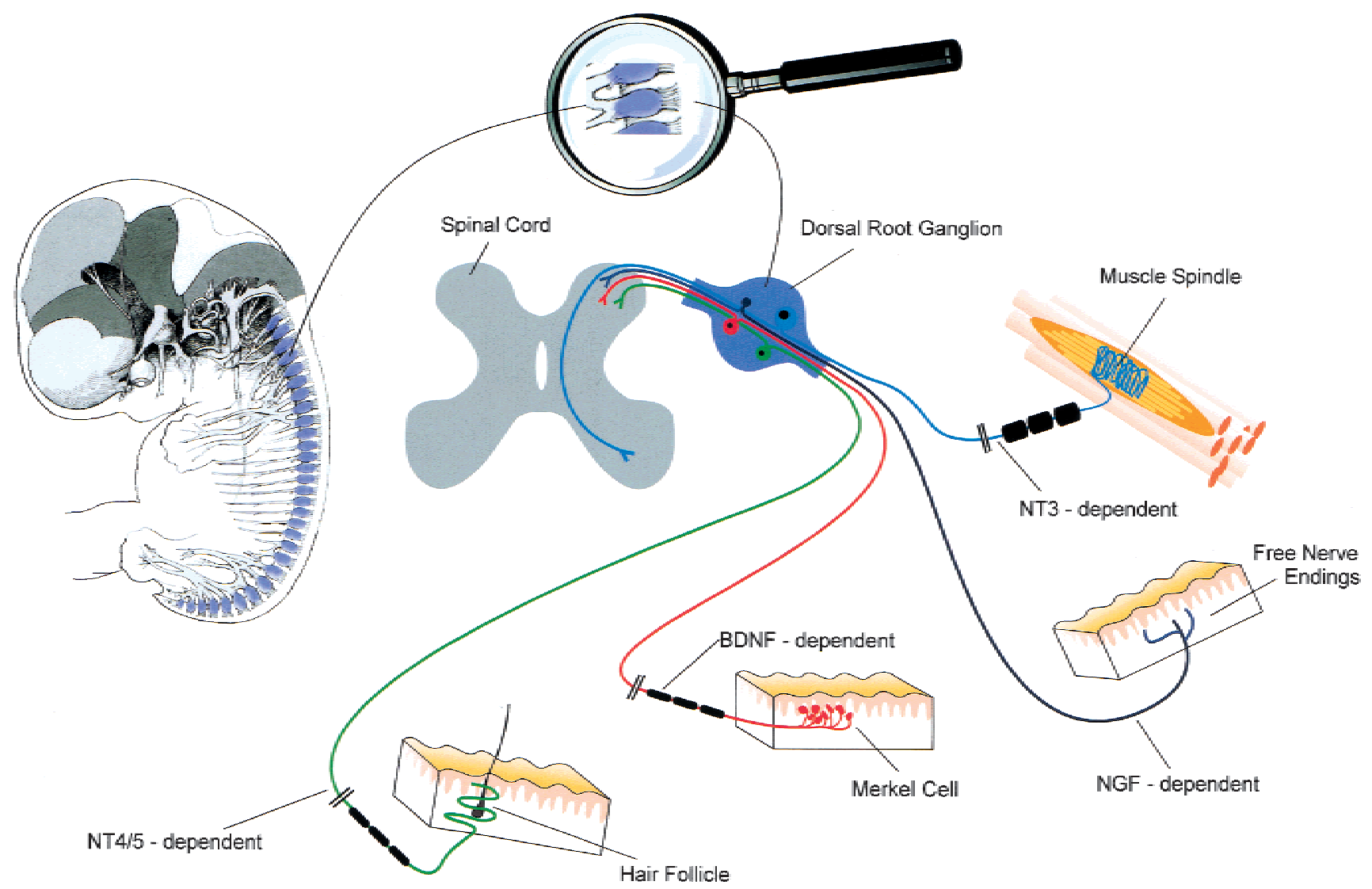

Figure 4. Neurotrophins control the development of specific subpopulations of sensory neurons. Sensory neurons of the dorsal root ganglia (DRGs) have specific patterns of projection both in the spinal cord and in the periphery, and they also transmit specific sensory modalities. NGF is necessary for the survival of essentially all small neurons with unmyelinated or thinly myelinated axons (black). BDNF affects the development of mechano-receptors terminating on Merkel cells (red), whereas NT4/5 is necessary for the development of deep-hair cell afferents (green). NT3 supports the survival of many DRG neurons early in development (blue). These include large neurons with thickly myelinated axons innervating muscle spindles and the organ of Golgi in the tendons of muscles. 
survival action, explaining why the neuronal losses in trkC-/- animals are smaller than expected (Davies et al. 1995). In line with these in vivo observations, previous biochemical studies had indicated that NT3 can bind to and activate not only its preferred receptor TrkC but also TrkB and TrkA (Barbacid 1994), a property that is modulated by the coexpression of p75 (Bibel et al. 1999). In this context, it is interesting to note that experiments with mouse mutants have indicated that in the absence of p75, NT3 becomes an efficient TrkA ligand for sympathetic neurons (Brennan et al. 1999).

Other striking examples of specific neurotrophin requirements have been obtained in the auditory and vestibular systems (for a recent review, see Fritzsch et al. 2000), as well as in visceral sensory ganglia (Brady et al. 1999).

Sympathetic ganglia The demonstration that NGF antibodies cause the loss of peripheral sympathetic ganglia was the first piece of experimental evidence ever demonstrating an absolute requirement of certain cells for a specific survival factor (Cohen 1960; Levi-Montalcini and Booker 1960). This seminal observation took place long before the mechanisms leading to death of animal cells were understood. Experiments with mice carrying mutations in the $n g f$ gene confirmed the dependency of most sympathetic neurons on NGF for survival. As with sensory neurons, the phenotype of trkA-/- and ngf-/animals is remarkably similar (Fagan et al. 1996). Unexpectedly, NT3 was also shown to be required for the survival of about half the number of cranial sympathetic neurons. This conclusion was reached both with antibodies blocking the function of NT3 (Zhou and Rush 1995) and with nt3-/- mutants (Ernfors et al. 1994; Fariñas et al. 1994). The situation is especially intriguing from the point of view of receptor usage, as TrkC is expressed by sympathetic neurons only prenatally in rodents, during a time period when NT3 does not seem to be required for survival (Wyatt et al. 1997). There is now good evidence that NT3 exerts its survival action through TrkA (Wyatt et al. 1997; Brennan et al. 1999). Taken together, these results suggest that a significant proportion of sympathetic neurons require both NT3 and NGF for survival during a brief postnatal period. This leaves the prenatal role of the NT3/TrkC signaling system open in prenatal sympathetic neurons. Recent results obtained with avian neurons indicate that the NT3/TrkC system promotes the cholinergic differentiation of sympathetic neurons (Brodski et al. 2000). This result is especially intriguing, as the same neurons seem to express both TrkA and TrkC (Brodski et al. 2000). Yet the activation of TrkA by NGF promotes adrenergic differentiation, suggesting that signaling downstream of TrkA and TrkC can lead to surprisingly different outcomes in the same cells.

Central nervous system The survival role of neurotrophins in the developing CNS has been more difficult to assess than their role in the peripheral nervous system. One of the problems lies in the identification and counting of reasonably homogenous populations of neurons. No decreases were found in the number of spinal cord motoneurons in $b d n f / n t 4 / 5$ double mutants (Liu et al. 1995) or of ganglion cells in the retina (bdnf-/-; Cellerino et al. 1997). However, it was noted that in bdnf-/-, the axonal diameters of optic nerve axons were reduced and, perhaps as a consequence, that myelination was decreased (Cellerino et al. 1997).

In the brain, studies with mice carrying single or double mutations in the trkB and trkC genes have indicated postnatal cell death in the hippocampus and the cerebral cortex (Minichiello and Klein 1996; Alcántara et al. 1997). Also, foliation abnormalities and reduced cell numbers have been noted in the cerebellum of bdnf-/mutants (Schwartz et al. 1997). At this point it is not entirely clear if these neuronal losses (often recorded as increased number of TUNEL+ cells) are a direct consequence of the mutation, given the massive and early effects of these mutations in the peripheral nervous system. However, two recent studies indicate that the TrkB signaling system is essential in the adult CNS. Both used postnatal, cre-mediated deletion of TrkB in forebrain neurons (Minichiello et al. 1999; Xu et al. 2000). Clear reductions in the size of the cerebral cortex have been observed, very likely caused by a decrease in size of the neurons, of their dendrites, and presumably of their numbers as well (see below).

With regard to the situation after nerve section, at least some neurons depend on neurotrophins for survival. In particular, most retinal ganglion cells eventually die after section of the optic nerve, and a significant proportion can be rescued following the administration of BDNF or of NT4/5 (Sawai et al. 1996). In the corticospinal tract, recent work indicates that endogenous BDNF is essential to prevent the death of a significant proportion of the axotomized neurons. Interestingly, endogenous NT3 seems to cause the death of these neurons (K. Giehl and M. Meyer, pers. comm.).

\section{Neurotrophins cause programmed cell death}

The observation that neurotrophins kill cells during development is comparatively recent and still incompletely understood. It is largely a consequence of work aimed at understanding the biological role of the neurotrophin receptor p75. In particular, overexpression of p75 in transgenic mice causes the death of a very large number of neurons in the developing CNS (Majdan et al. 1997). Experiments with cultured oligodendrocytes indicated that they up-regulate p75 expression with time in culture and that they can be killed by the addition of NGF (Casaccia-Bonnefil et al. 1996). That ligand-mediated cell death may be operative in vivo was first shown in the developing avian retina. Experiments in chick embryos using antibodies blocking the biological activity of either NGF or of p75 (Frade et al. 1996) or in the mouse using animals carrying mutations in the corresponding genes (Frade and Barde 1999) indicated a reduction of programmed cell death. Similar results were obtained in the developing mouse neural tube (Frade and Barde 
1999). Cell death in both structures correlates with the development of axonal tracts, resulting in the formation of the optic nerve and the commissural pathway, and cell elimination seems to be accelerated by a NGF/p75-dependent mechanism.

NGF does not seem to be the only ligand able to activate p75 to cause cell death. In developing sympathetic ganglia, evidence has been provided that BDNF can activate p75 to cause cell death and that both $b d n f-/-$ and p75-/- mutants have larger numbers of sympathetic neurons (Bamji et al. 1998). In line with this, the addition of BDNF to cultured sympathetic neurons can kill them (Bamji et al. 1998).

However, p75 expression by developing neurons is by no means a predictor of cell death. Not only do many more neurons express p75 than die (see below) but, also, p75 is expressed by several other cell types, including all neural crest derivatives, where its function is still not clear. This is one of the reasons why it is difficult to predict the consequences of the lack of p75 expression. With spinal cord motoneurons or DRG neurons, for example, the number of neurons is actually decreased in p75-/- animals (Stucky and Koltzenburg 1997; Wiese et al. 1999; see also Lee et al. 1992). As axonal elongation is retarded in these animals (Yamashita et al. 1999b), the decrease in cell numbers may be an indirect consequence of the lack of $\mathrm{p} 75$, for example, by retarding the access of developing neurons to target-derived survival factors. The in vitro observation indicating that NGF kills motoneurons is also difficult to interpret, as it may well result from competition for receptor occupancy (Wiese et al. 1999). Basal forebrain cholinergic neurons also express p75 at high levels, but reports linking the expression of p75 with the number of cholinergic neurons are controversial (Van der Zee et al. 1996, but see Ward and Hagg 1999; Yeo et al. 1997, but see Peterson et al. 1997). However, recent work using a mutation of $p 75$ eliminating both p75 transcripts indicates that there is a substantial increase in the number of basal forebrain cholinergic neurons determined $2 \mathrm{wk}$ after birth in such animals (G. Dechant et al., pers. comm.). In addition, it seems that the number of cholinergic neurons differs significantly depending on the genetic background of the animals (E. Casademunt and M. Frotscher, pers. comm.).

\section{Neurotrophins regulate the growth of neuronal processes}

NGF was purified following its ability to induce neurite outgrowth from peripheral ganglia embedded in a plasma clot (Levi-Montalcini et al. 1954; Cohen 1960), thus suggesting from the beginning that neurotrophins may promote axon elongation (for review of the early literature, see Levi-Montalcini and Angeletti 1968).

\section{Peripheral nervous system}

In vivo work with sympathetic ganglia revealed that NGF levels regulate dendritic growth (Fig. 5). In adult rats, not only does the administration of NGF cause dendritic length to increase but, also, the administration of NGF-antibodies decreases it (Ruit et al. 1990). Interestingly, the increased number of dendrites induced by NGF is accompanied by a very large increase in the number of preganglionic axons innervating NGF-responsive ganglia (Schafer et al. 1983). To eliminate the problem of neuronal death in the $n g f$ or $\operatorname{trk} A-/-$ animals, Snider and colleagues crossed each mutant with mice carrying a deletion in the proapoptotic gene bax (Patel et al. 2000). Although the total neuronal numbers were actually larger than in wild-type mice, a dramatic reduction in the number of peripheral sensory axons was observed at birth, though it is not known if the nerves grew earlier in development and subsequently retracted. These results suggest that either elongation or maintenance of peripheral axons in vivo requires NGF. By contrast, the growth of axons into the spinal cord was apparently normal, both in terms of axonal numbers and of territory of projections. At this point, it is unclear if the observations made with NGF and DRG also apply to other neurotrophins and ganglia. For example, axons of the trigeminal ganglion only have short distances to travel to reach their target areas, and in mice carrying mutations both in the $n t 3$ and in the $b d n f$ genes, trigeminal axons seem to grow quite normally $\left(\mathrm{O}^{\prime}\right.$ Connor and Tessier-Lavigne 1999/. In vitro, there is good evidence that neurotrophins, like the netrins, can act as guidance cues for growth cones (for review, see Song and Poo 1999).

Recently, a method has been developed allowing the visualization of peripheral nerves in the mouse as they grow out toward their targets in their normal environment. This was made possible through the introduction of the green fluorescent protein into the tau locus. The local application of a combination of monoclonal antibodies to NGF, BDNF, and NT3 led to a marked reduction in the elongation of both sensory and motor nerves. These results indicate that neurotrophins are indeed required in vivo for the growth of peripheral nerves. In addition, the use of the same strategy allowed the demonstration that all four neurotrophins are able to attract sensory nerves when placed ectopically, on the side of the pathway followed by peripheral nerves (K. Tucker, pers. comm.).

\section{Central nervous system}

Clear evidence that neurotrophins regulate axonal branching during the development of CNS neurons came from work with Xenopus tadpoles. BDNF injection into the optic tectum led to increased arborization of ganglion axon terminals, whereas blocking endogenous BDNF had the opposite effect (Cohen-Cory and Fraser 1995; Cohen-Cory 1999).

The use of CNS tissue slices and of organotypic cultures has made it possible to explore the potential of neurotrophins with regard to their dendritic growth-promoting activity. In slices of ferret visual cortex, BDNF, $\mathrm{NT} 4 / 5$, and NT3 were shown to increase within $2 \mathrm{~d}$ the length and the complexity of dendrites of pyramidal neu- 


\section{Sympathetic Neurons}
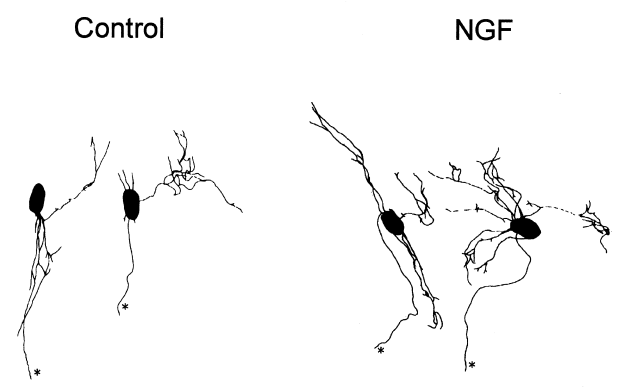

Pyramidal Neurons
Control

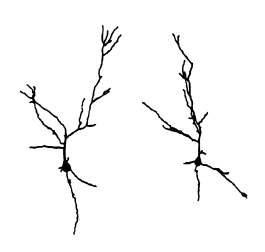

BDNF

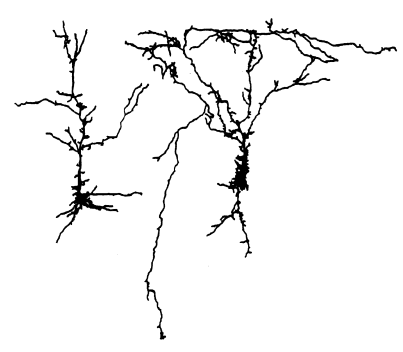

Anti-NGF

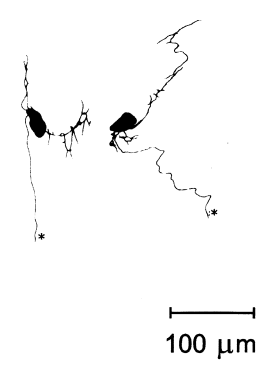

$100 \mu \mathrm{m}$
$A P V+B D N F$

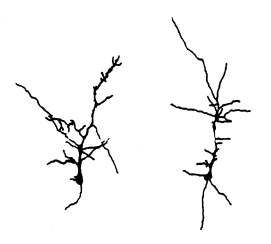

rons (McAllister et al. 1995). Remarkably, the effects turned out to be different for apical or basal dendrites and specific for each neurotrophin tested. These results suggest that each neurotrophin acts instructively to modulate particular patterns of dendritic arborization. In complementary experiments, McAllister and colleagues showed that the neutralization of endogenous neurotrophins also leads to remarkable effects. In particular, BDNF and NT3 seem to antagonize each other's role (McAllister et al. 1997). For example, NT3 limits the growth-promoting action of BDNF in layer 4 of the cerebral cortex, whereas in layer six BDNF counteracts the action of NT3. Most importantly, the regulation of cortical dendritic growth by neurotrophins requires endogeneous electrical activity (McAllister et al. 1996). Some of the effects of neurotrophins on dendritic growth and, especially, retraction are not easy to account for given our present knowledge of the role and function of neurotrophin receptors. In particular, whereas NGF has been reported to affect apical dendrites, it appears that neither p75 nor TrkA are expressed by the responsive neurons. The possibilities exist, then, that unidentified NGF receptors may mediate its action or that the effects are indirect and necessitate the presence of other cells.

The length of distal dendrites can also be affected by increased expression of the truncated receptor TrkB (Yacoubian and Lo 2000). This is in contrast with the
Figure 5. Neurotrophins modify the shape of neurons. (Top) Sympathetic neurons of the adult rat superior cervical ganglion were filled with a fluorescent dye, and the morphology of cell bodies, dendrites, and axons (asterisk) was monitored in control, NGFtreated, or NGF antibody-treated animals (Ruit et al. 1990; Fig. 2). (Bottom) The morphology of pyramidal cells was visualized following the introduction of lacZ-expressing plasmids in slices of the ferret visual cortex. BDNF, as well as APV, was bath applied to the slices. APV (2-amino-5-phosphono-valerate) is a glutamate receptor antagonist, and glutamate is the major excitatory neurotransmitter in the cerebral cortex. In the absence of glutamate receptor-mediated activity, the effects of BDNF on the dendritic morphology are blocked (McAllister et al. 1997; Fig. 2).

effects of full-length TrkB, which increases the branching of proximal dendrites, whereas truncated TrkB decreases it. In vivo, a recent study indicates that the cremediated deletion of all forms of TrkB leads to a marked reduction in the length of dendrites of pyramidal neurons in the cortex (Xu et al. 2000).

\section{Neurotrophins and synaptic transmission}

Neurotrophins not only modulate dendritic growth but also the number of synapses and the efficacy of synaptic transmission. Manipulations of NGF levels were shown early on to regulate both the strength and the number of presynaptic inputs (Nja and Purves 1978). In mice overexpressing BDNF in sympathetic neurons, increased numbers of synapses were observed, whereas decreases were seen in bdnf-/- animals (Causing et al. 1997). In the hippocampus of mice carrying mutations in trkB, trkC, or in both genes, lower densities of synaptic contact were recorded in the hippocampus. Presynaptic alterations were also noted, including decreased numbers of synaptic vesicles (Martinez et al. 1998). In line with these findings, quantitative analyses of hippocampal synapses of $b d n f-/-$ animals revealed a significant reduction in the number of vesicles docked at presynaptic active zones. Synaptosomes prepared from the mutant hippocampus exhibited a marked decrease in the levels of 
synaptophysin as well as synaptobrevin. The deficits can be corrected by the acute administration of BDNF to slices (Pozzo-Miller et al. 1999). These results suggest a role for BDNF in the mobilization and/or docking of synaptic vesicles to presynaptic active zones (see below).

The first indication that neurotrophins can rapidly modulate neurotransmission came from in vitro experiments with dissociated cells from Xenopus laevis embryos. Both NT3 and BDNF were shown to increase acetylcholine release within minutes of application (Lohof et al. 1993). Numerous subsequent experiments with CNS neurons confirmed and extended these initial observations (for review, see Schuman 1999), and it appears that the increase in neurotransmitter release by BDNF involves phosphorylation of synapsins (Jovanovic et al. 2000).

The time course of neurotrophin effects on neurons can be surprisingly rapid for molecules initially thought to have mostly long-term, growth-promoting types of actions. In particular, recent observations indicate that neurotrophins can alter the functional state of neurons within milliseconds (Kafitz et al. 1999). BDNF and NT4/5 (NT3 to a much lesser extent) were shown to cause depolarization and elicit action potential in pyramidal cells of the hippocampus or cortex and in Purkinje cells of the cerebellum. This depolarization results from an increased conductance for sodium ions, and it is as rapid as that induced by the neurotransmitter glutamate. Remarkably, the effects of the neurotrophins can be recorded at a more than a thousand-fold lower concentration. The molecular basis of these observations is unclear at this point. The results suggest that the TrkB occupancy by BDNF or NT4/5 would modulate the permeability of an ion channel associated with TrkB. Interestingly, it has recently been shown that TrkB codistributes and associates with the cation channel TRPC3 (Li et al. 1999). BDNF binding to TrkB leads to a TRPC3-dependent cation influx in CNS neurons through the activation of phospholipase $\mathrm{C} \gamma$.

One of the clearest indications that neurotrophins, and BDNF in particular, modulate synaptic transmission comes from the much studied paradigm of long-term potentiation. Not only is LTP compromised (at Schaffer collateral-CA1 synapses) when hippocampal slices are prepared from $b d n f-/-$ or even $b d n f_{+} /-$animals (Korte et al. 1995), but it can also be restored when BDNF is added to the slices (Korte et al. 1996; Patterson et al. 1996). In addition, deprivation of BDNF by the acute application of reagents blocking the activity of BDNF also compromises the establishment of LTP. NT3 does not seem to be involved, as agents specifically blocking NT3 are without effects (Chen et al. 1999). At present, it is unclear just exactly how BDNF participates in LTP. With the data currently available, it is not possible to distinguish between a mainly pre- or postsynaptic action of BDNF. There is good evidence for both pre- and postsynaptic effects (for review, see Schumann 1999). BDNF is also involved in a newly identified form of synaptic plasticity acting to stabilize the firing rates of cortical neurons, thereby maintaining responsiveness to different strengths of synaptic input. The quantal amplitude of excitatory input is scaled up or down as a function of neuronal activity. TrkB-Fc fusion proteins mimic the effects of activity blockade on pyramidal quantal amplitude, whereas exogeneous BDNF prevented them (Rutherford et al. 1998).

Whereas little is still known about the exact localization of BDNF in the hippocampus, it appears likely that it is present both pre- and postsynaptically. Clearly, the effects of BDNF require the catalytic form of the receptor $\operatorname{TrkB}$, as the selective, postnatal ablation of TrkB in the hippocampus also severely compromises LTP (Minichiello et al. 1999). At present, very little is known about the subcellular compartments storing neurotrophins. These are unlikely to be classical synaptic vesicles, as there is evidence that neurotrophin release is not strictly dependent on extracellular calcium (Blöchl and Thoenen 1995). Recent electron microscopic data indicate that the compartments are contained in endoplasmic reticulumlike compartments partially associated with microtubules (Gärtner et al. 2000).

Neurotrophins have also been shown to be involved in one of the best-studied models of activity-dependent developmental plasticity in the CNS, namely, the establishment of ocular dominance columns in the visual cortex (for review, see McAllister et al. 1999). Blocking the input from one eye leads to the shrinkage of the corresponding neuronal cell bodies and axons in the lateral geniculate nucleus, and the input from the nondeprived eye takes over. Early experiments with NGF in the rat indicated that the consequences of monocular deprivation can be prevented by the administration of NGF (Maffei et al. 1992). Conversely, NGF-antibodies prevent normal visual system development (Berardi et al. 1994). In more recent experiments using latex beads coated with NT4/5, the morphological consequences of monocular deprivation could be prevented in the lateral geniculate nucleus (Riddle et al. 1995). Surprisingly, BDNF was without effect. The development of ocular dominance columns in ferrets was shown to be blocked by both the addition or the neutralization of endogenous BDNF or NT4/5, suggesting that both may be involved in the competition of axons in layer 4 of the cortex (Cabelli et al. 1995, 1997).

Whereas these results all indicate that neurotrophins are somehow involved in the activity-dependent segregation of inputs to the visual cortex, the precise mechanisms and the identity of the neurotrophins involved are still somewhat unclear.

In rodents, the levels of BDNF rise substantially postnatally. This process was accelerated in mice carrying a construct in which BDNF was placed under the control of a calcium calmodulin kinase promoter (Huang et al. 1999). This resulted in the precocious maturation of (inhibitory) GABAergic innervation (GABAergic neurons are a major target of BDNF in the CNS). Interestingly, the age-dependent decline of cortical long-term potentiation occurred earlier in these transgenic animals. Also, the mice showed a precocious development of visual acuity and an earlier termination of the critical period for 
ocular dominance plasticity (Hanover et al. 1999). These results suggest that by promoting the maturation of cortical inhibition during early postnatal life, BDNF is involved in the regulation of the critical period for visual cortical plasticity (Huang et al. 1999).

\section{Neurotrophins and behavior}

Whereas all neurotrophin null mutants are eventually lethal (with the exception of $n t 4 / 5$ ), detailed explorations of the heterozygotes and of animals carrying conditional gene knock out have begun to reveal interesting results with regard to behavior. TrkB-deficient animals were generated using a floxed TrkB allele and cre recombinase under the control of the calmodulin kinase promoter (Minichiello et al. 1999; Xu et al. 2000). The levels of the tyrosine kinase-containing form of TrkB were found to be normal at birth but to subsequently decrease by $\sim 80 \%$ in the hippocampus and the anterior forebrain while remaining normal in other structures such as the cerebellum or the brain stem (Minichiello et al. 1999). The selective postnatal ablation of TrkB revealed a substantial reduction of LTP in the hippocampus. Also, these animals became increasingly impaired over time with regard to their spatial learning behavior. Extensive behavioral tests of these mice indicate that they behave as if they had a hippocampal lesion (for details, see Minichiello et al. 1999).

Another interesting approach has been the study of $b d n f+/-$ animals. Young adults (in which the induction of LTP is compromised) show learning deficits (Linnarsson et al. 1997) and, although they have a normal life span, they develop an enhanced aggressiveness and hyperphagia, accompanied with weight gain in early adulthood (Lyons et al. 1999; Kernie et al. 2000). These findings are reminiscent of dysfunctions of the serotoninergic system, and BDNF is known to have trophic effects on serotoninergic neurons (Mamounas et al. 2000). Interestingly, the heightened aggressiveness can be ameliorated by selectively inhibiting serotonin reuptake. Furthermore, the levels of serotonin and the density of serotoninergic axons are decreased in $b d n f_{+} /-$animals. Alterations in the expression of several serotonin receptors have also been noted in the cerebral cortex, the hippocampus, and the hypothalamus. With regard to weight control, it has been noted that TrkB and BDNF transcripts are localized in satiety and locomotor hypothalamic nuclei. The infusion of either BDNF or NT4/5 over a period of $16 \mathrm{~d}$ led to a $30 \%$ weight loss, which correlated with a decrease in size of adipocytes. Ninety days following the end of the treatment, the mice had regained their pretreatment weight.

In nonmammalian species, an interesting correlation has been noted between the availability of BDNF and the ability of canaries to learn new songs (Rasika et al. 1999). New neurons are incorporated into the so-called high vocal center (HVC) of canaries, which plays a critical role in the acquisition of learned songs. This recruitment is testosterone-dependent. BDNF is strongly and selectively enriched in the HVC, and testosterone treatment increases the levels of BDNF in the female HVC. It also triples the number of new neurons in the female HVC. Conversely, injections of BDNF antibodies into the HVC blocks the testosterone-induced increase of new neurons, thus suggesting that BDNF is involved in the regulation of neuronal replacement in the adult canary brain. With regard to the generation of new cells in the adult brain, it is also interesting to note that BDNF infusion markedly increases the number of newly generated neurons in the adult rat olfactory bulb, by increasing either their generation or their survival (Zigova et al. 1998). A likely endogenous source of BDNF for newly generated neurons in the adult rat subependymal zone are vascular endothelial cells that contain and secrete BDNF but not other neurotrophins (Leventhal et al. 1999).

It appears, then, that BDNF may be implicated in complex behavioral pattern, and it can be predicted that conditional knock-out approaches will reveal a wide range of actions of the neurotrophins in the adult CNS. With regard to cognitive functions, it had been noted early on that the administration of NGF to age-impaired rats significantly ameliorates their cognitive performance, presumably as a result of the action of NGF on the cholinergic forebrain neurons (Fischer et al. 1987). How an increasingly detailed knowledge of the actions of neurotrophins in the adult CNS can be used to stop the progression of neurodegenerative diseases and to ameliorate cognitive functions in the aging human nervous system remains a major and important challenge for the future.

\section{Acknowledgments}

We thank our colleagues Martin Korte and Kerry Tucker for very helpful comments and Harry Schnürch for Figure 4.

\section{References}

Alcántara, S., Frisén, J., Del Río, J.A., Soriano, E., Barbacid, M., and Silos-Santiago, I. 1997. TrkB signaling is required for postnatal survival of CNS neurons and protects hippocampal and motor neurons from axotomy-induced cell death. J. Neurosci. 17: 3623-3633.

Bamji, S.X., Majdan, M., Pozniak, C.D., Belliveau, D.J., Aloyz, R., Kohn, J., Causing, C.G., and Miller, F.D. 1998. The p75 neurotrophin receptor mediates neuronal apoptosis and is essential for naturally occurring sympathetic neuron death. J. Cell Biol. 140: 911-923.

Barbacid, M. 1994. The trk family of neurotrophin receptors. J. Neurobiol. 25: 1386-1403.

Barde, Y.-A. 1990. The nerve growth factor family. Prog. Growth Factor Res. 2: 237-348.

Barde, Y.-A., Edgar, D., and Thoenen, H. 1982. Purification of a new neurotrophic factor from mammalian brain. $E M B O J$. 1: $549-553$.

Bargmann, C.I. 1998. Neurobiology of the Caenorhabditis elegans genome. Science 282: 2028-2033.

Barker, P.A. 1998. p75NTR: A study in contrasts. Cell Death and Differ. 5: 346-356.

Barker, P.A. and Shooter, E.M. 1994. Disruption of NGF binding to the low affinity neurotrophin receptor p75LNTR reduces 
NGF binding to TrkA on PC12 cells. Neuron 13: 203-215.

Barker, P.A., Barbee, G., Misko, T.P., and Shooter, E.M. 1994. The low affinity neurotrophin receptor, p75LNTR, is palmitoylated by thioester formation through cysteine 279. J. Biol. Chem. 269: 30645-30650.

Barrett, G.L. and Bartlett, P.F. 1994. The p75 nerve growth factor receptor mediates survival or death depending on the stage of sensory neuron development. Proc. Natl. Acad. Sci. 91: 6501-6505.

Barsh, G. 1999. Of ancient tales and hairless tails. Nat. Genet. 22: 315-316.

Belliveau, D.J., Krivko, I., Kohn, J., Lachance, C., Pozniak, C., Rusakov, D., Kaplan, D., and Miller, F.D. 1997. NGF and neurotrophin-3 both activate TrkA on sympathetic neurons but differentially regulate survival and neuritogenesis. J. Cell Biol. 136: 375-388.

Benedetti, M., Levi, A., and Chao, M.V. 1993. Differential expression of nerve growth factor receptors leads to altered binding affinity and neurotrophin responsiveness. Proc. Natl. Acad. Sci. 90: 7859-7863.

Berardi, N., Cellerino, A., Domenici, L., Fagiolini, M., Pizzorusso, T., Cattaneo, A., and Maffei, L. 1994. Monoclonal antibodies to nerve growth factor affect the postnatal development of the visual system. Proc. Natl. Acad. Sci. 91: 684688.

Bhattacharyya, A., Watson, F.L., Bradlee, T.A., Pomeroy, S.L., Stiles, C.D., and Segal, R.A. 1997. Trk receptors function as rapid retrograde signal carriers in the adult nervous system. J. Neurosci. 17: 7007-7016.

Bibel, M., Hoppe, E., and Barde, Y.A. 1999. Biochemical and functional interactions between the neurotrophin receptors trk and p75NTR. EMBO I. 18: 616-622.

Biffo, S., Offenhauser, N., Carter, B.D., and Barde, Y.A. 1995. Selective binding and internalisation by truncated receptors restrict the availability of BDNF during development. Development 121: 2461-2470.

Bilderback, T.R., Grigsby, R.J., and Dobrowsky, R.T. 1997. Association of p75(NTR) with caveolin and localization of neurotrophin-induced sphingomyelin hydrolysis to caveolae. $J$. Biol. Chem. 272: 10922-10927.

Bilderback, T.R., Gazula, V.R., Lisanti, M.P., and Dobrowsky, R.T. 1999. Caveolin interacts with Trk A and p75(NTR) and regulates neurotrophin signaling pathways. J. Biol. Chem. 274: 257-263.

Blöchl, A. and Sirrenberg, C. 1996. Neurotrophins stimulate the release of dopamine from rat mesencephalic neurons via Trk and p75 ${ }^{\text {LNTR }}$ receptors. J. Biol. Chem. 271: 21100-21107.

Blöchl, A. and Thoenen, H. 1995. Characterization of nerve growth factor (NGF) release from hippocampal neurons: Evidence for a constitutive and an unconventional sodium-dependent regulated pathway. Eur. J. Neurosci. 7: 1220-1228.

Bothwell, M. 1995. Functional interactions of neurotrophins and neurotrophin receptors. Annu. Rev. Neurosci. 18: 223253.

Brady, R., Zaidi, S.I., Mayer, C., and Katz, D.M. 1999. BDNF is a target-derived survival factor for arterial baroreceptor and chemoafferent primary sensory neurons. I. Neurosci. 19: 2131-2142.

Brennan, C., Rivas-Plata, K., and Landis, S.C. 1999. The p75 neurotrophin receptor influences NT-3 responsiveness of sympathetic neurons in vivo. Nat. Neurosci. 2: 699-705.

Brodski, C., Schnürch, H., and Dechant, G. 2000. Neurotrophin-3 promotes the cholinergic differentiation of sympathetic neurons. Proc. Natl. Acad. Sci. 97: 9683-9688.

Brunet, A., Bonni, A., Zigmond, M.J., Lin, M.Z., Juo, P., Hu, L.S.,
Anderson, M.J., Arden, K.C., Blenis, J., and Greenberg, M.E. 1999. Akt promotes cell survival by phosphorylating and inhibiting a Forkhead transcription factor. Cell 96: 857-868.

Cabelli, R.J., Hohn, A., and Shatz, C.J. 1995. Inhibition of ocular dominance column formation by infusion of NT-4/5 or BDNF. Science 267: 1662-1666.

Cabelli, R.J., Shelton, D.L., Segal, R.A., and Shatz, C.J. 1997. Blockade of endogenous ligands of trkB inhibits formation of ocular dominance columns. Neuron 19: 63-76.

Canossa, M., Twiss, J.L., Verity, A.N., and Shooter, E.M. 1996. p75(NGFR) and TrkA receptors collaborate to rapidly activate a p75(NGFR)-associated protein kinase. EMBO $J$. 15: 3369-3376.

Canossa, M., Griesbeck, O., Berninger, B., Campana, G., Kolbeck, R., and Thoenen, H. 1997. Neurotrophin release by neurotrophins: Implications for activity-dependent neuronal plasticity. Proc. Natl. Acad. Sci. 94: 13279-13286.

Carroll, P., Lewin, G.R., Koltzenburg, M., Toyka, K.V., and Thoenen, H. 1998. A role for BDNF in mechanosensation. Nat. Neurosci. 1: 42-46.

Carter, B.D., Kaltschmidt, C., Kaltschmidt, B., Offenhauser, N., Böhm-Matthaei, R., Baeuerle, P.A., and Barde, Y.-A. 1996. Selective activation of NF-к B by nerve growth factor through the neurotrophin receptor p75. Science 272: 542545.

Casaccia-Bonnefil, P., Carter, B.D., Dobrowsky, R.T., and Chao, M.V. 1996. Death of oligodendrocytes mediated by the interaction of nerve growth factor with its receptor p75. Nature 383: 716-719.

Casademunt, E., Carter, B.D., Benzel, I., Frade, J.M., Dechant, G., and Barde, Y.A. 1999. The zinc finger protein NRIF interacts with the neurotrophin receptor $\mathrm{p} 75(\mathrm{NTR})$ and participates in programmed cell death. EMBO J. 18: 6050-6061.

Causing, C.G., Gloster, A., Aloyz, R., Bamji, S.X., Chang, E., Fawcett, J., Kuchel, G., and Miller, F.D. 1997. Synaptic innervation density is regulated by neuron-derived BDNF. Neuron 18: 257-267.

Cellerino, A., Carroll, P., Thoenen, H., and Barde, Y.A. 1997. Reduced size of retinal ganglion cell axon and hypomyelination in mice lacking brain-derived neurotrophic factor. Mol. Cell Neurosci. 9: 397-408.

Chao, M.V. and Hempstead, B.L. 1995. p75 and Trk: A tworeceptor system. Trends Neurosci. 18: 321-326.

Chapman, B.S. 1995. A region of the $75 \mathrm{kDa}$ neurotrophin receptor homologous to the death domains of TNFR-I and Fas. FEBS Lett. 374: 216-220.

Chen, G.Q., Kolbeck, R., Barde, Y.A., Bonhoeffer, T., and Kossel, A. 1999. Relative contribution of endogenous neurotrophins in hippocampal long-term potentiation. I. Neurosci. 19: 7983-7990.

Chittka, A. and Chao, M.V. 1999. Identification of a zinc finger protein whose subcellular distribution is regulated by serum and nerve growth factor. Proc. Nat1. Acad. Sci. 96: 1070510710.

Clary, D.O. and Reichardt, L.F. 1994. An alternatively spliced form of the nerve growth factor receptor TrkA confers an enhanced response to neurotrophin 3. Proc. Natl. Acad. Sci. 91: 11133-11137.

Cohen, S. 1960. Purification of a nerve-growth promoting protein from the mouse salivary gland and its neuro-cytotoxic antiserum. Proc. Natl. Acad. Sci. 46: 302-311.

Cohen-Cory, S. 1999. BDNF modulates, but does not mediate, activity-dependent branching and remodeling of optic axon arbors in vivo. J. Neurosci. 19: 9996-10003.

Cohen-Cory, S. and Fraser, S.E. 1995. Effects of brain-derived 
neurotrophic factor on optic axon branching and remodelling in vivo. Nature 378: 192-196.

Coulson, E.J., Reid, K., Barrett, G.L., and Bartlett, P.F. 1999. p75 neurotrophin receptor-mediated neuronal death is promoted by Bcl-2 and prevented by Bcl-xL. J. Biol. Chem. 274: 1638716391.

Crowder, R.J. and Freeman, R.S. 1998. Phosphatidylinositol 3-kinase and Akt protein kinase are necessary and sufficient for the survival of nerve growth factor-dependent sympathetic neurons. J. Neurosci. 18: 2933-2943.

Cunningham, M.E. and Greene, L.A. 1998. A function-structure model for NGF-activated TRK. EMBO J. 17: 7282-7293.

Datta, S.R., Dudek, H., Tao, X., Masters, S., Fu, H.A., Gotoh, Y., and Greenberg, M.E. 1997. Akt phosphorylation of BAD couples survival signals to the cell-intrinsic death machinery. Cell 91: 231-241.

Davey, F. and Davies, A.M. 1998. TrkB signaling inhibits p75mediated apoptosis induced by nerve growth factor in embryonic proprioceptive neurons. Curr. Biol. 8: 915-918.

Davies, A.M. 1994. The role of neurotrophins in the developing nervous system. J. Neurobiol. 25: 1334-1348.

Davies, A.M., Lee, K.F., and Jaenisch, R. 1993. p75-deficient trigeminal sensory neurons have an altered response to NGF but not to other neurotrophins. Neuron 11: 565-574.

Davies, A.M., Minichiello, L., and Klein, R. 1995. Developmental changes in NT3 signaling via TrkA and TrkB in embryonic neurons. EMBO T. 14: 4482-4489.

Dechant, G. and Barde, Y.A. 1997. Signaling through the neurotrophin receptor p75NTR. Curr. Opin. Neurobiol. 7: 413418.

Dechant, G., Tsoulfas, P., Parada, L.F., and Barde, Y.A. 1997. The neurotrophin receptor p75 binds neurotrophin-3 on sympathetic neurons with high affinity and specificity. $J$. Neurosci. 17: 5281-5287.

Dikic, I., Batzer, A.G., Blaikie, P., Obermeier, A., Ullrich, A., Schlessinger, J., and Margolis, B. 1995. Shc binding to nerve growth factor receptor is mediated by the phosphotyrosine interaction domain. J. Biol. Chem. 270: 15125-15129.

Dobrowsky, R.T., Werner, M.H., Castellino, A.M., Chao, M.V., and Hannun, Y.A. 1994. Activation of the sphingomyelin cycle through the low-affinity neurotrophin receptor. Science 265: 1596-1599.

Dobrowsky, R.T., Jenkins, G.M., and Hannun, Y.A. 1995. Neurotrophins induce sphingomyelin hydrolysis: Modulation by co-expression of p75NTR with Trk receptors. J. Biol. Chem. 270: 22135-22142.

Easton, J.B., Moody, N.M., Zhu, X.Y., and Middlemas, D.S. 1999. Brain-derived neurotrophic factor induces phosphorylation of fibroblast growth factor receptor substrate 2. J. Biol. Chem. 274: 11321-11327.

Eide, F.F., Vining, E.R., Eide, B.L., Zang, K., Wang, X.Y., and Reichardt, L.F. 1996. Naturally occurring truncated trkB receptors have dominant inhibitory effects on brain-derived neurotrophic factor signaling. J. Neurosci. 16: 3123-3129.

Ernfors, P., Lee, K.-F., Kucera, J., and Jaenisch, R. 1994. Lack of neurotrophin-3 leads to deficiencies in the peripheral nervous system and loss of limb proprioceptive afferents. Cell 77: 503-512.

Fagan, A.M., Zhang, H., Landis, S., Smeyne, R.J., Silos-Santiago, I., and Barbacid, M. 1996. TrkA, but not TrkC, receptors are essential for survival of sympathetic neurons in vivo. J. Neurosci. 16: 6208-6218.

Fainzilber, M., Smit, A.B., Syed, N.I., Wildering, W.C., Hermann, P.M., Van der Schors, R.C., Jiménez, C., Li, K.W., van Minnen, J., Bulloch, A.G.M., et al. 1996. CRNF, a molluscan neurotrophic factor that interacts with the p75 neurotrophin receptor. Science 274: 1540-1543.

Fan, G., Egles, C., Sun, Y., Minichiello, L., Renger, J.J., Klein, R., Liu, G., and Jaenisch, R. 2000. Knocking the NT4 gene into the BDNF locus rescues BDNF deficient mice and reveals distinct NT4 and BDNF activities. Nat. Neurosci. 3: 350357.

Fariñas, I., Jones, K.R., Backus, C., Wang, X.-Y., and Reichardt, L.F. 1994. Severe sensory and sympathetic deficits in mice lacking neurotrophin-3. Nature 369: 658-661.

Fariñas, I., Wilkinson, G.A., Backus, C., Reichardt, L.F., and Patapoutian, A. 1998. Characterization of neurotrophin and Trk receptor functions in developing sensory ganglia: Direct NT-3 activation of TrkB neurons in vivo. Neuron 21: 325334.

Feinstein, D.L. and Larhammar, D. 1990. Identification of a conserved protein motif in a group of growth factor receptors. FEBS Lett. 272: 7-11.

Feinstein, E., Kimchi, A., Wallach, D., Boldin, M., and Varfolomeev, E. 1995. The death domain: A module shared by proteins with diverse cellular functions. Trends Biochem. Sci. 20: 342-344.

Finkbeiner, S. 2000. CREB couples neurotrophin signals to survival messages. Neuron 25: 11-14.

Finkbeiner, S., Tavazoie, S.F., Maloratsky, A., Jacobs, K.M., Harris, K.M., and Greenberg, M.E. 1997. CREB: A major mediator of neuronal neurotrophin responses. Neuron 19: 10311047.

Fischer, W., Wictorin, K., Bjoerklund, A., Williams, L.R., Varon, S., and Gage, F.H. 1987. Amelioration of cholinergic neuron atrophy and spatial memory impairment in aged rats by nerve growth factor. Nature 329: 65-68.

Frade, J.M. and Barde, Y.A. 1999. Genetic evidence for cell death mediated by nerve growth factor and the neurotrophin receptor p75 in the developing mouse retina and spinal cord. Development 126: 683-690.

Frade, J.M., Rodriguez-Tebar, A., and Barde, Y.A. 1996. Induction of cell death by endogenous nerve growth factor through its p75 receptor. Nature 383: 166-168.

Franke, T.F., Kaplan, D.R., and Cantley, L.C. 1997. PI3K: Downstream AKTion blocks apoptosis. Cell 88: 435-437.

Friedman, W.J. and Greene, L.A. 1999. Neurotrophin signaling via Trks and p75. Exp. Cell Res. 253: 131-142.

Fritzsch, B., Silos-Santiago, I., Bianchi, L.M., and Fariñas, I. 2000. Effects of neurotrophin and neurotrophin receptor disruption on the afferent inner ear innervation. Semin. Cell Dev. Biol. 8: 277-284.

Fryer, R.H., Kaplan, D.R., Feinstein, S.C., Radeke, M.J., Grayson, D.R., and Kromer, L.F. 1996. Developmental and mature expression of full-length and truncated TrkB receptors in the rat forebrain. J. Comp. Neurol. 374: 21-40.

Gärtner, A., Shostak, Y., Hackel, N., Ethell, I.M., and Thoenen, H. 2000. Ultrastructural identification of storage compartments and localization of activity-dependent secretion of neurotrophin 6 in hippocampal neurons. Mol. Cell. Neurosci. 15: 215-234.

Grell, M. and Clauss, M. 2000. TNF and TNF receptor superfamily. Int. Rev. Immunol. (in press).

Grimes, M.L., Zhou, J., Beattie, E.C., Yuen, E.C., Hall, D.E., Valletta, J.S., Topp, K.S., Lavail, J.H., Bunnett, N.W., and Mobley, W.C. 1996. Endocytosis of activated TrkA: Evidence that nerve growth factor induces formation of signaling endosomes. J. Neurosci. 16: 7950-7964.

Hadari, Y.R., Kouhara, H., Lax, I., and Schlessinger, J. 1998. Binding of Shp2 tyrosine phosphatase to FRS2 is essential for 
fibroblast growth factor-induced PC12 cell differentiation. Mol. Cell. Biol. 18: 3966-3973.

Hallböök, F. 1999. Evolution of the vertebrate neurotrophin and Trk receptor gene families. Cur. Opin. Neurobiol. 9: 616621.

Hamanoue, M., Middleton, G., Wyatt, S., Jaffray, E., Hay, R.T., and Davies, A.M. 1999. p75-mediated NF-кB activation enhances the survival response of developing sensory neurons to nerve growth factor. Mol. Cell. Neurosci. 14: 28-40.

Hanover, J.L., Huang, Z.J., Tonegawa, S., and Stryker, M.P. 1999. Brain-derived neurotrophic factor overexpression induces precocious critical period in mouse visual cortex. $J$. Neurosci. 19: NIL12-NIL16.

Headon, D.J. and Overbeek, P.A. 1999. Involvement of a novel Tnf receptor homolog in hair follicle induction. Nat. Genet. 22: 370-374.

Hempstead, B.L., Martin-Zanca, D., Kaplan, D.R., Parada, L.F., and Chao, M.V. 1991. High-affinity NGF binding requires coexpression of the trk proto-oncogene and the low-affinity NGF receptor. Nature 350: 678-683.

Hofer, M.M. and Barde, Y.-A. 1988. Brain-derived neurotrophic factor prevents neuronal death in vivo. Nature 331: 261-262.

Holgado-Madruga, M., Moscatello, D.K., Emlet, D.R., Dieterich, R., and Wong, A.J. 1997. Grb2-associated binder-1 mediates phosphatidylinositol 3-kinase activation and the promotion of cell survival by nerve growth factor. Proc. Natl. Acad. Sci. 94: 12419-12424.

Horton, A., Laramee, G., Wyatt, S., Shih, A., Winslow, J., and Davies, A.M. 1997. NGF binding to p75 enhances the sensitivity of sensory and sympathetic neurons to NGF at different stages of development. Mol. Cell. Neurosci. 10: 162-172.

Huang, Z.J., Kirkwood, A., Pizzorusso, T., Porciatti, V., Morales, B., Bear, M.F., Maffei, L., and Tonegawa, S. 1999. BDNF regulates the maturation of inhibition and the critical period of plasticity in mouse visual cortex. Cell 98: 739-755.

Ibáñez, C.F. 1998. Emerging themes in structural biology of neurotrophic factors. Trends Neurosci. 21: 438-444.

Irie, S., Hachiya, T., Rabizadeh, S., Maruyama, W., Mukai, J., Li, Y., Reed, J.C., Bredesen, D.E., and Sato, T.A. 1999. Functional interaction of Fas-associated phosphatase-1 (FAP-1) with p75(NTR) and their effect on NF-кB activation. FEBS Lett. 460: 191-198.

Jiang, Y.P., Woronicz, J.D., Liu, W., and Goeddel, D.V. 1999. Prevention of constitutive TNF receptor 1 signaling by silencer of death domains. Science 283: 543-546.

Jing, S., Tapley, P., and Barbacid, M. 1992. Nerve growth factor mediates signal transduction through trk homodimer receptors. Neuron 9: 1067-1079.

Johnson, D., Lanahan, A., Buck, C.R., Sehgal, A., Morgan, C., Mercer, E., Bothwell, M., and Chao, M. 1986. Expression and structure of the human NGF receptor. Cell 47: 545-554.

Jovanovic, J.N., Czernik, A.J., Fienberg, A.A., and Greengard, P. 2000. Synapsins as mediators of BDNF-enhanced neurotransmitter release. Nat. Neurosci. 3: 323-329.

Kafitz, K.W., Rose, C.R., Thoenen, H., and Konnerth, A. 1999. Neurotrophin-evoked rapid excitation through TrkB receptors. Nature 401: 918-921.

Kaplan, D.R. and Miller, F.D. 2000. Neurotrophin signal transduction in the nervous system. Curr. Opin. Neurobiol. 10: 381-391.

Kaplan, D.R., Hempstead, B.L., Martin-Zanca, D., Chao, M.V., and Parada, L.F. 1991. The trk proto-oncogene product: A signal transducing receptor for nerve growth factor. Science 252: 554-558.

Kernie, S.G., Liebl, D.J., and Parada, L.F. 2000. BDNF regulates eating behavior and locomotor activity in mice. $E M B O \mathrm{~J}$. 19: $1290-1300$.

Khursigara, G., Orlinick, J.R., and Chao, M.V. 1999. Association of the p75 neurotrophin receptor with TRAF6. J. Biol. Chem. 274: 2597-2600.

Klein, R., Conway, D., Parada, L.F., and Barbacid, M. 1990. The trkB tyrosine protein kinase gene codes for a second neurogenic receptor that lacks the catalytic kinase domain. Cell 61: 647-656.

Klein, R., Jing, S.Q., Nanduri, V., O'Rourke, E., and Barbacid, M. 1991. The trk proto-oncogene encodes a receptor for nerve growth factor. Cell 65: 189-197.

Koch, G., Haberman, B., Mohr, C., Just, I., and Aktories, K. 1991. Interaction of mastoparan with the low molecular mass GTP-binding proteins rho/rac. FEBS Lett. 291: 336340.

Kornau, H.C., Schenker, L.T., Kennedy, M.B., and Seeburg, P.H. 1995. Domain interaction between NMDA receptor subunits and the postsynaptic density protein PSD-95. Science 269: $1737-1740$.

Korte, M., Carroll, P., Wolf, E., Brem, G., Thoenen, H., and Bonhoeffer, T. 1995. Hippocampal long-term potentiation is impaired in mice lacking brain-derived neurotrophic factor. Proc. Nat1. Acad. Sci. 92: 8856-8860.

Korte, M., Griesbeck, O., Gravel, C., Carroll, P., Staiger, V., Thoenen, H., and Bonhoeffer, T. 1996. Virus-mediated gene transfer into hippocampal CA1 region restores long-term potentiation in brain-derived neurotrophic factor mutant mice. Proc. Natl. Acad. Sci. 93: 12547-12552.

Kouhara, H., Hadari, Y.R., Spivak-Kroizman, T., Schilling, J. Bar-Sagi, D., Lax, I., and Schlessinger, J. 1997. A lipid-anchored Grb2-binding protein that links FGF-receptor activation to the Ras/MAPK signaling pathway. Cell 89: 693-702.

Lee, K.F., Li, E., Huber, L.J., Landis, S.C., Sharpe, A.H., Chao, M.V., and Jaenisch, R. 1992. Targeted mutation of the gene encoding the low affinity NGF receptor p75 leads to deficits in the peripheral sensory nervous system. Cell 69: 737-749.

Lee, K.F., Davies, A.M., and Jaenisch, R. 1994. p75-deficient embryonic dorsal root sensory and neonatal sympathetic neurons display a decreased sensitivity to NGF. Development 120: 1027-1033

Leventhal, C., Rafii, S., Rafii, D., Shahar, A., and Goldman, S.A. 1999. Endothelial trophic support of neuronal production and recruitment from the adult mammalian subependyma. Mol. Cell. Neurosci. 13: 450-464.

Levi-Montalcini, R. 1966. The nerve growth factor: Its mode of action on sensory and sympathetic nerve cells. Harvey Lect. 60: $217-259$.

Levi-Montalcini, R. and Angeletti, P.U. 1968. Biological aspects of the nerve growth factor. Physiol. Rev. 48: 126-147.

Levi-Montalcini, R. and Booker, B. 1960. Destruction of the sympathetic ganglia in mammals by an antiserum to a nerve growth protein. Proc. Nat1. Acad. Sci. 46: 384-391.

Levi-Montalcini, R., Meyer, H., and Hamburger, V. 1954. In vitro experiments on the effects of mouse sarcomas 180 and 37 on the spinal and sympathetic ganglia of the chick embryo. Cancer Res. 14: 49-57.

Li, H.S., Xu, X.Z., and Montell, C. 1999. Activation of a TRPC3dependent cation current through the neurotrophin BDNF. Neuron 24: 261-273.

Liepinsh, E., Ilag, L.L., Otting, G., and Ibáñez, C.F. 1997. NMR structure of the death domain of the p75 neurotrophin receptor. EMBO I. 16: 4999-5005.

Linnarsson, S., Björklund, A., and Ernfors, P. 1997. Learning deficit in BDNF mutant mice. Eur. J. Neurosci. 9: 
$2581-2587$.

Liu, X., Ernfors, P., Wu, H., and Jaenisch, R. 1995. Sensory but not motor neuron deficits in mice lacking NT4 and BDNF. Nature 375: 238-241.

Liu, Z.G., Hsu, H., Goeddel, D.V., and Karin, M. 1996. Dissection of TNF receptor 1 effector functions: JNK activation is not linked to apoptosis while NF-кB activation prevents cell death. Cell 87: 565-576.

Loeb, D.M., Stephens, R.M., Copeland, T., Kaplan, D.R., and Greene, L.A. 1994. A Trk nerve growth factor (NGF) receptor point mutation affecting interaction with phospholipase C- $\gamma 1$ abolishes NGF-promoted peripherin induction but not neurite outgrowth. I. Biol. Chem. 269: 8901-8910.

Lohof, A.M., Ip, N.Y., and Poo, M. 1993. Potentiation of developing neuromuscular synapses by the neurotrophins NT-3 and BDNF. Nature 363: 350-353.

Lyons, W.E., Mamounas, L.A., Ricaurte, G.A., Coppola, V., Reid, S.W., Bora, S.H., Wihler, C., Koliatsos, V.E., and Tessarollo, L. 1999. Brain-derived neurotrophic factor-deficient mice develop aggressiveness and hyperphagia in conjunction with brain serotonergic abnormalities. Proc. Natl. Acad. Sci. 96: 15239-15244.

Maffei, L., Berardi, N., Domenici, L., Parisi, V., and Pizzorusso, T. 1992. Nerve growth factor (NGF) prevents the shift in ocular dominance distribution of visual cortical neurons in monocularly deprived rats. J. Neurosci. 12: 4651-4662.

Maggirwar, S.B., Sarmiere, P.D., Dewhurst, S., and Freeman, R.S. 1998. Nerve growth factor-dependent activation of NF$\kappa \mathrm{B}$ contributes to survival of sympathetic neurons. I. Neurosci. 18: 10356-10365.

Mahadeo, D., Kaplan, L., Chao, M.V., and Hempstead, B.L. 1994. High affinity nerve growth factor binding displays a faster rate of association than p140trk binding: Implications for multi-subunit polypeptide receptors. I. Biol. Chem. 269: 6884-6891.

Majdan, M., Lachance, C., Gloster, A., Aloyz, R., Zeindler, C., Bamji, S., Bhakar, A., Belliveau, D., Fawcett, J., Miller, F.D., et al. 1997. Transgenic mice expressing the intracellular domain of the p75 neurotrophin receptor undergo neuronal apoptosis. J. Neurosci. 17: 6988-6998.

Mamounas, L.A., Altar, C.A., Blue, M.E., Kaplan, D.R., Tessarollo, L., and Lyons, W.E. 2000. BDNF promotes the regenerative sprouting, but not survival, of injured serotonergic axons in the adult rat brain. J. Neurosci. 20: 771-782.

Martinez, A., Alcantara, S., Borrell, V., Del Rio, J.A., Blasi, J., Otal, R., Campos, N., Boronat, A., Barbacid, M., Silos-Santiago, I., et al. 1998. TrkB and TrkC signaling are required for maturation and synaptogenesis of hippocampal connections. J. Neurosci. 18: 7336-7350.

Matsuda, M., Hashimoto, Y., Muroya, K., Hasegawa, H., Kurata, T., Tanaka, S., Nakamura, S., and Hattori, S. 1994. CRK protein binds to two guanine nucleotide-releasing proteins for the Ras family and modulates nerve growth factor-induced activation of Ras in PC12 cells. Mol. Cell. Biol. 14: 5495-5500.

McAllister, A.K., Lo, D.C., and Katz, L.C. 1995. Neurotrophins regulate dendritic growth in developing visual cortex. Neuron 15: 791-803.

McAllister, A.K., Katz, L.C., and Lo, D.C. 1996. Neurotrophin regulation of cortical dendritic growth requires activity. Neuron 17: 1057-1064.

- 1997. Opposing roles for endogenous BDNF and NT-3 in regulating cortical dendritic growth. Neuron 18: 767-778.

1999. Neurotrophins and synaptic plasticity. Annu. Rev. Neurosci. 22: 295-318.
McDonald, N.Q. and Hendrickson, W.A. 1993. A structural superfamily of growth factors containing a cystine knot motif. Cell 73: 421-424.

McDonald, N.Q., Lapatto, R., Murray-Rust, J., Gunning, J., Wlodawer, A., and Blundell, T.L. 1991. New protein fold revealed by a $2.3-\AA$ resolution crystal structure of nerve growth factor. Nature 354: 411-414.

Meakin, S.O., MacDonald, J.I., Gryz, E.A., Kubu, C.J., and Verdi, J.M. 1999. The signaling adapter FRS-2 competes with Shc for binding to the nerve growth factor receptor TrkA: A model for discriminating proliferation and differentiation. $J$. Biol. Chem. 274: 9861-9870.

Middlemas, D.S., Lindberg, R.A., and Hunter, T. 1991. trkB, a neural receptor protein-tyrosine kinase: Evidence for a fulllength and two truncated receptors. Mol. Cell. Biol. 11: 143153.

Minichiello, L. and Klein, R. 1996. TrkB and TrkC neurotrophin receptors cooperate in promoting survival of hippocampal and cerebellar granule neurons. Genes \& Dev. 10: 28492858.

Minichiello, L., Casagranda, F., Tatche, R.S., Stucky, C.L., Postigo, A., Lewin, G.R., Davies, A.M., and Klein, R. 1998. Point mutation in trkB causes loss of NT4-dependent neurons without major effects on diverse BDNF responses. Neuron 21: 335-345.

Minichiello, L., Korte, M., Wolfer, D., Kühn, R., Unsicker, K., Cestari, V., Rossi-Arnaud, C., Lipp, H.P., Bonhoeffer, T., and Klein, R. 1999. Essential role for TrkB receptors in hippocampus-mediated learning. Neuron 24: 401-414.

Mukai, J., Hachiya, T., Shoji-Hoshino, S., Kimura, M.T. Nadano, D., Suvanto, P., Hanaoka, T., Li, Y., Irie, S., Greene, L.A., et al. 2000. NADE, a p75NTR-associated cell death executor, is involved in signal transduction mediated by the common neurotrophin receptor p75NTR. J. Biol. Chem. 275: $17566-17570$.

Nakamura, T., Muraoka, S., Sanokawa, R., and Mori, N. 1998. N-Shc and Sck, two neuronally expressed Shc adapter homologs: Their differential regional expression in the brain and roles in neurotrophin and Src signaling. J. Biol. Chem. 273: 6960-6967.

Ninkina, N., Adu, J., Fischer, A., Pinon, L.G., Buchman, V.L., and Davies, A.M. 1996. Expression and function of TrkB variants in developing sensory neurons. EMBO J. 15: 63856393.

Nja, A. and Purves, D. 1978. The effects of nerve growth factor and its antiserum on synapses in the superior cervical ganglion of the guinea-pig. J. Physiol. 277: 53-75.

Obermeier, A., Bradshaw, R.A., Seedorf, K., Choidas, A., Schlessinger, J., and Ullrich, A. 1994. Neuronal differentiation signals are controlled by nerve growth factor receptor/ Trk binding sites for SHC and PLCgamma. EMBO J. 13: 1585-1590.

O'Connor, R. and Tessier-Lavigne, M. 1999. Identification of maxillary factor, a maxillary process-derived chemoattractant for developing trigeminal sensory axons. Neuron 24: $165-178$.

Oppenheim, R.W. 1991. Cell death during development of the nervous system. Annu. Rev. Neurosci. 14: 453-501.

Patel, T.D., Jackman, A., Rice, F.L., Kucera, J., and Snider, W.D. 2000. Development of sensory neurons in the absence of NGF/TrkA signaling in vivo. Neuron 25: 345-357.

Patterson, S.L., Abel, T., Deuel, T.A.S., Martin, K.C., Rose, J.C., and Kandel, E.R. 1996. Recombinant BDNF rescues deficits in basal synaptic transmission and hippocampal LTP in BDNF knockout mice. Neuron 16: 1137-1145. 
Peng, X., Greene, L.A., Kaplan, D.R., and Stephens, R.M. 1995. Deletion of a conserved juxtamembrane sequence in trk abolishes NGF-promoted neuritogenesis. Neuron 15: 395406.

Peterson, D.A., Leppert, J.T., Lee, K.F., and Gage, F.H. 1997. Basal forebrain neuronal loss in mice lacking neurotrophin receptor p75. Science 277: 837-839.

Pozniak, C.D., Radinovic, S., Yang, A., McKeon, F., Kaplan, D.R., and Miller, F.D. 2000. An anti-apoptotic role for the p53 family member, p73, during developmental neuron death. Science 289: 304-306.

Pozzo-Miller, L.D., Gottschalk, W., Zhang, L., McDermott, K., Du, J., Gopalakrishnan, R., Oho, C., Sheng, Z.H., and Lu, B. 1999. Impairments in high-frequency transmission, synaptic vesicle docking, and synaptic protein distribution in the hippocampus of BDNF knockout mice. I. Neurosci. 19: 49724983.

Purves, D. 1988. Body and brain: A trophic theory of neural connections. Harvard University Press, Cambridge, MA.

Qian, X.Z., Riccio, A., Zhang, Y., and Ginty, D.D. 1998. Identification and characterization of novel substrates of $\operatorname{TrK}$ receptors in developing neurons. Neuron 21: 1017-1029.

Rabin, S.J., Cleghon, V., and Kaplan, D.R. 1993. SNT, a differentiation-specific target of neurotrophic factor-induced tyrosine kinase activity in neurons and PC12 cells. Mol. Cell. Biol. 13: 2203-2213.

Rabizadeh, S., Oh, J., Zhong, L.T., Yang, J., Bitler, C.M., Butcher, L.L., and Bredesen, D.E. 1993. Induction of apoptosis by the low-affinity NGF receptor. Science 261: 345-348.

Radeke, M.J., Misko, T.P., Hsu, C., Herzenberg, L.A., and Shooter, E.M. 1987. Gene transfer and molecular cloning of the rat nerve growth factor receptor. Nature 325: 593-597.

Rasika, S., Alvarez-Buylla, A., and Nottebohm, F. 1999. BDNF mediates the effects of testosterone on the survival of new neurons in an adult brain. Neuron 22: 53-62.

Riccio, A., Pierchala, B.A., Ciarallo, C.L., and Ginty, D.D. 1997. An NGF-TrkA-mediated retrograde signal to transcription factor CREB in sympathetic neurons. Science 277: 10971100.

Rice, F.L., Albers, K.M., Davis, B.M., Silos-Santiago, I., Wilkinson, G.A., LeMaster, A.M., Ernfors, P., Smeyne, R.J., Aldskogius, H., Phillips, H.S., et al. 1998. Differential dependency of unmyelinated and A $\delta$ epidermal and upper dermal innervation on neurotrophins, trk receptors, and $\mathrm{p} 75^{\text {LNGFR }}$. Dev. Biol. 198: 57-81.

Riddle, D.R., Lo, D.C., and Katz, L.C. 1995. NT-4-mediated rescue of lateral geniculate neurons from effects of monocular deprivation. Nature 378: 189-191.

Rodriguez-Tébar, A., Dechant, G., and Barde, Y.-A. 1990. Binding of brain-derived neurotrophic factor to the nerve growth factor receptor. Neuron 4: 487-492.

Roux, P.P., Colicos, M.A., Barker, P.A., and Kennedy, T.E. 1999. p75 neurotrophin receptor expression is induced in apoptotic neurons after seizure. J. Neurosci. 19: 6887-6896.

Rubenstein, J.L., Shimamura, K., Martinez, S., and Puelles, L. 1998. Regionalization of the prosencephalic neural plate. Annu. Rev. Neurosci. 21: 445-477.

Ruit, K.G., Osborne, P.A., Schmidt, R.E., Johnson Jr., E.M., and Snider, W.D. 1990. Nerve growth factor regulates sympathetic ganglion cell morphology and survival in the adult mouse. J. Neurosci. 10: 2412-2419.

Rutherford, L.C., Nelson, S.B., and Turrigiano, G.G. 1998. BDNF has opposite effects on the quantal amplitude of pyramidal neuron and interneuron excitatory excitaory synapses. Neuron 21: 521-530.
Salehi, A.H., Roux, P.P., Kubu, C.J., Zeindler, C., Bhakar, A., Tannis, L.-L., Verdi, J.M., and Barker, P.A. 2000. NRAGE, a novel MAGE protein, interacts with the p75 neurotrophin receptor and facilitates nerve growth factor-dependent apoptosis. Neuron 27: 279-288.

Sawai, H., Clarke, D.B., Kittlerova, P., Bray, G.M., and Aguayo, A.J. 1996. Brain-derived neurotrophic factor and neurotrophin- $4 / 5$ stimulate growth of axonal branches from regenerating retinal ganglion cells. J. Neurosci. 16: 3887-3894.

Schafer, T., Schwab, M.E., and Thoenen, H. 1983. Increased formation of preganglionic synapses and axons due to a retrograde trans-synaptic action of nerve growth factor in the rat sympathetic nervous system. J. Neurosci. 3: 1501-1520.

Schneider, R. and Schweiger, M. 1991. A novel modular mosaic of cell adhesion motifs in the extracellular domains of the neurogenic trk and trkB tyrosine kinase receptors. Oncogene 6: $1807-1811$.

Schuman, E.M. 1999. Neurotrophin regulation of synaptic transmission. Curr. Opin. Neurobiol. 9: 105-109.

Schwartz, P.M., Borghesani, P.R., Levy, R.L., Pomeroy, S.L., and Segal, R.A. 1997. Abnormal cerebellar development and foliation in $B D N F^{-/-}$mice reveals a role for neurotrophins in CNS patterning. Neuron 19: 269-281.

Senger, D.L. and Campenot, R.B. 1997. Rapid retrograde tyrosine phosphorylation of trkA and other proteins in rat sympathetic neurons in compartmented cultures. J. Cell Biol. 138: 411-421.

Shelton, D.L., Sutherland, J., Gripp, J., Camerato, T., Armanini, M.P., Phillips, H.S., Carroll, K., Spencer, S.D., and Levinson, A.D. 1995. Human trks: Molecular cloning, tissue distribution, and expression of extracellular domain immunoadhesins. J. Neurosci. 15: 477-491.

Silva, A.J., Kogan, J.H., Frankland, P.W., and Kida, S. 1998. CREB and memory. Annu. Rev. Neurosci. 21: 127-148.

Smith, C.A., Farrah, T., and Goodwin, R.G. 1994. The TNF receptor superfamily of cellular and viral proteins: Activation, costimulation, and death. Cell 76: 959-962.

Snider, W.D. 1994. Functions of the neurotrophins during nervous system development: What the knockouts are teaching us. Cell 77: 627-638.

Soilu-Hänninen, M., Ekert, P., Bucci, T., Syroid, D., Bartlett, P.F., and Kilpatrick, T.J. 1999. Nerve growth factor signaling through p75 induces apoptosis in Schwann cells via a Bcl-2independent pathway. J. Neurosci. 19: 4828-4838.

Song, H.J. and Poo, M.M. 1999. Signal transduction underlying growth cone guidance by diffusible factors. Curr. Opin. Neurobiol. 9: 355-363.

Stephens, R.M., Loeb, D.M., Copeland, T.D., Pawson, T., Greene, L.A., and Kaplan, D.R. 1994. Trk receptors use redundant signal transduction pathways involving SHC and PLC-gammal to mediate NGF responses. Neuron 12: 691705.

Strohmaier, C., Carter, B.D., Urfer, R., Barde, Y.A., and Dechant, G. 1996. A splice variant of the neurotrophin receptor trkB with increased specificity for brain-derived neurotrophic factor. $E M B O$ J. 15: 3332-3337.

Stucky, C.L. and Koltzenburg, M. 1997. The low-affinity neurotrophin receptor p75 regulates the function but not the selective survival of specific subpopulations of sensory neurons. J. Neurosci. 17: 4398-4405.

Tao, X., Finkbeiner, S., Arnold, D.B., Shaywitz, A.J., and Greenberg, M.E. 1998. $\mathrm{Ca}^{2+}$ influx regulates $B D N F$ transcription by a CREB family transcription factor-dependent mechanism. Neuron 20: 709-726.

Tessarollo, L., Tsoulfas, P., Martin-Zanca, D., Gilbert, D.J., Jen- 
kins, N.A., Copeland, N.G., and Parada, L.F. 1993. trkC, a receptor for neurotrophin-3, is widely expressed in the developing nervous system and in non-neuronal tissues. Development 118: 463-475.

Thoenen, H. 1995. Neurotrophins and neuronal plasticity. Science 270: 593-598.

Torres, M. and Bogenmann, E. 1996. Nerve growth factor induces a multimeric TrkA receptor complex in neuronal cells that includes Crk, SHC and PLC-gamma 1 but excludes P130CAS. Oncogene 12: 77-86.

Tuffereau, C., Benejean, J., Blondel, D., Kieffer, B., and Flamand, A. 1998. Low-affinity nerve-growth factor receptor (P75NTR) can serve as a receptor for rabies virus. EMBO $J$. 17: 7250-7259.

Urfer, R., Tsoulfas, P., O'Connell, L., Shelton, D.L., Parada, L.F., and Presta, L.G. 1995. An immunoglobulin-like domain determines the specificity of neurotrophin receptors. EMBO $J$. 14: 2795-2805.

Urfer, R., Tsoulfas, P., O'Connell, L., Hongo, J.A., Zhao, W., and Presta, L.G. 1998. High resolution mapping of the binding site of TrkA for nerve growth factor and TrkC for neurotrophin-3 on the second immunoglobulin-like domain of the Trk receptors. J. Biol. Chem. 273: 5829-5840.

Van der Zee, C.E., Ross, G.M., Riopelle, R.J., and Hagg, T. 1996. Survival of cholinergic forebrain neurons in developing p75NGFR-deficient mice. Science 274: 1729-1732.

van Kesteren, R.E., Fainzilber, M., Hauser, G., van Minnen, J., Vreugdenhil, E., Smit, A.B., Ibáñez, C.F., Geraerts, W.P., and Bulloch, A.G. 1998. Early evolutionary origin of the neurotrophin receptor family. EMBO J. 17: 2534-2542.

Volonté, C., Angelastro, J.M., and Greene, L.A. 1993. Association of protein kinases ERK1 and ERK2 with p75 nerve growth factor receptors. J. Biol. Chem. 268: 21410-21415.

Ward, N.L. and Hagg, T. 1999. p $75^{\text {NGFR }}$ and cholinergic neurons in the developing forebrain: A re-examination. Dev. Brain Res. 118: 79-91.

Wiegmann, K., Schütze, S., Machleidt, T., Witte, D., and Krönke, M. 1994. Functional dichotomy of neutral and acidic sphingomyelinases in tumor necrosis factor signaling. Cell 78: 1005-1015.

Wiese, S., Metzger, F., Holtmann, B., and Sendtner, M. 1999. The role of $\mathrm{p} 75^{\mathrm{NTR}}$ in modulating neurotrophin survival effects in developing motoneurons. Eur. J. Neurosci. 11: 16681676.

Wiesmann, C., Ultsch, M.H., Bass, S.H., and de Vos, A.M. 1999. Crystal structure of nerve growth factor in complex with the ligand-binding domain of the TrkA receptor. Nature 401: 184-188.

Williams, R.W. and Herrup, K. 1988. The control of neuron number. Annu. Rev. Neurosci. 11: 423-453.

Wright, J.H., Drueckes, P., Bartoe, J., Zhao, Z., Shen, S.H., and Krebs, E.G. 1997. A role for the SHP-2 tyrosine phosphatase in nerve growth-induced PC12 cell differentiation. Mol. Biol. Cell 8: 1575-1585.

Wyatt, S., Piñón, L.G.P., Ernfors, P., and Davies, A.M. 1997. Sympathetic neuron survival and TrkA expression in NT3deficient mouse embryos. EMBO J. 16: 3115-3123.

Xu, B.J., Zang, K.L., Ruff, N.L., Zhang, Y.A, McConnell, S.K., Stryker, M.P., and Reichardt, L.F. 2000. Cortical degeneration in the absence of neurotrophin signaling: Dendritic retraction and neuronal loss after removal of the receptor TrkB. Neuron 26: 236-245.

Yacoubian, T. and Lo, D.C. 2000. Truncated and full-length TrkB receptors regulate distinct modes of dendritic growth. Nat. Neurosci. 3: 342-349.
Yamada, M., Ohnishi, H., Sano, S., Nakatani, A., Ikeuchi, T., and Hatanaka, H. 1997. Insulin receptor substrate (IRS)-1 and IRS-2 are tyrosine-phosphorylated and associated with phosphatidylinositol 3-kinase in response to brain-derived neurotrophic factor in cultured cerebral cortical neurons. J. Biol. Chem. 272: 30334-30339.

Yamashita, H., Avraham, S., Jiang, S.X., Dikic, I., and Avraham, H. 1999a. The Csk homologous kinase associates with TrkA receptors and is involved in neurite outgrowth of PC12 cells. J. Biol. Chem. 274: 15059-15065.

Yamashita, T., Tucker, K.L., and Barde, Y.A. 1999b. Neurotrophin binding to the p75 receptor modulates Rho activity and axonal outgrowth. Neuron 24: 585-593.

Ye, X., Mehlen, P., Rabizadeh, S., VanArsdale, T., Zhang, H., Shin, H., Wang, J.J., Leo, E., Zapata, J., Hauser, C.A., et al. 1999. TRAF family proteins interact with the common neurotrophin receptor and modulate apoptosis induction. J. Biol. Chem. 274: 30202-30208.

Yeo, T.T., Chua-Couzens, J., Butcher, L.L., Bredesen, D.E., Cooper, J.D., Valletta, J.S., Mobley, W.C., and Longo, F.M. 1997. Absence of $\mathrm{p} 75^{\mathrm{NTR}}$ causes increased basal forebrain cholinergic neuron size, choline acetyltransferase activity, and target innervation. J. Neurosci. 17: 7594-7605.

Yoon, S.O., Casaccia-Bonnefil, P., Carter, B., and Chao, M.V. 1998. Competitive signaling between TrkA and p75 nerve growth factor receptors determines cell survival. J. Neurosci. 18: 3273-3281.

York, R.D., Yao, H., Dillon, T., Ellig, C.L., Eckert, S.P., McCleskey, E.W., and Stork, P.J. 1998. Rap1 mediates sustained MAP kinase activation induced by nerve growth factor. $\mathrm{Na}$ ture 392: 622-626.

Zhou, X.F. and Rush, R.A. 1995. Sympathetic neurons in neonatal rats require endogenous neurotrophin-3 for survival. $J$. Neurosci. 15: 6521-6530.

Zigova, T., Pencea, V., Wiegand, S.J., and Luskin, M.B. 1998. Intraventricular administration of BDNF increases the number of newly generated neurons in the adult olfactory bulb. Mol. Cell. Neurosci. 11: 234-245.

Zupan, A.A., Osborne, P.A., Smith, C.E., Siegel, N.R., Leimgruber, R.M., and Johnson, Jr., E.M. 1989. Identification, purification, and characterization of truncated forms of the human nerve growth factor receptor. J. Biol. Chem. 264: 1171411720 . 


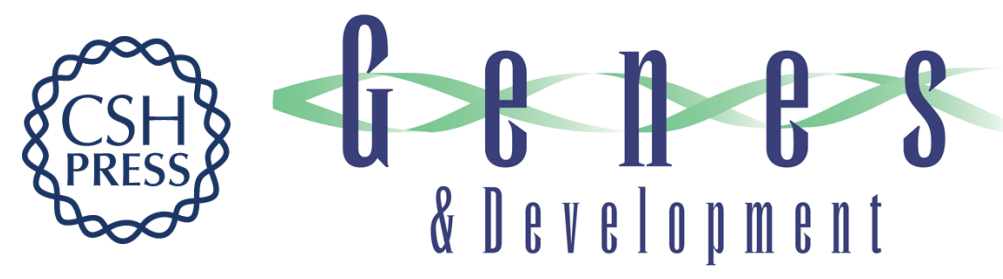

\section{Neurotrophins: key regulators of cell fate and cell shape in the vertebrate nervous system}

Miriam Bibel and Yves-Alain Barde

Genes Dev. 2000, 14:

Access the most recent version at doi:10.1101/gad.841400

References This article cites 208 articles, 93 of which can be accessed free at: http://genesdev.cshlp.org/content/14/23/2919.full.html\#ref-list-1

License

Email Alerting

Receive free email alerts when new articles cite this article - sign up in the box at the top Service right corner of the article or click here.

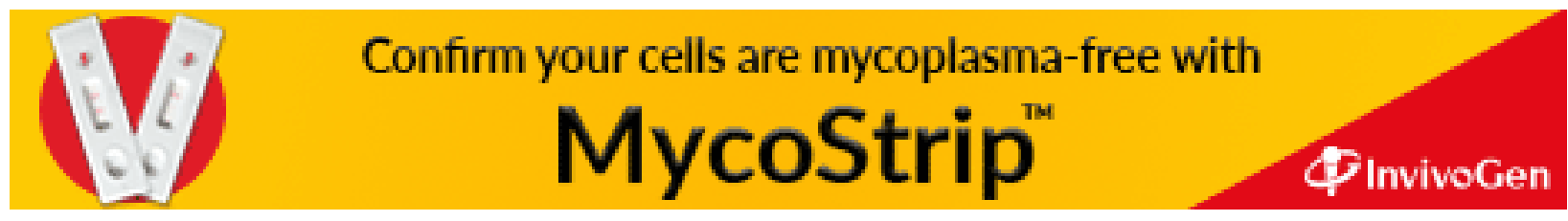

